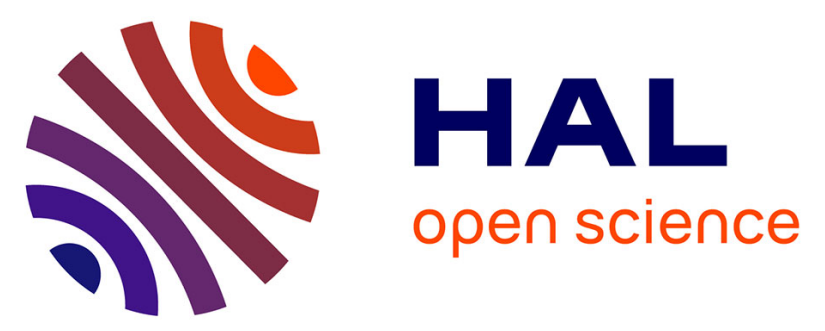

\title{
Structural and Luminescent Properties of Homoleptic Silver(I), Gold(I), and Palladium(II) Complexes with nNHC0-tz NHC Heteroditopic Carbene Ligands
}

\author{
Marco Monticelli, Marco Baron, Cristina Tubaro, Stéphane \\ Bellemin-Laponnaz, Claudia Graiff, Gregorio Bottaro, Lidia Armelao, Laura
}

Orian

\section{To cite this version:}

Marco Monticelli, Marco Baron, Cristina Tubaro, Stéphane Bellemin-Laponnaz, Claudia Graiff, et al.. Structural and Luminescent Properties of Homoleptic Silver(I), Gold(I), and Palladium(II) Complexes with nNHC0-tz NHC Heteroditopic Carbene Ligands. ACS Omega, 2019, 4 (2), pp.4192-4205. 10.1021/acsomega.8b03668 . hal-02332119

HAL Id: hal-02332119

https://hal.science/hal-02332119

Submitted on 24 Oct 2019

HAL is a multi-disciplinary open access archive for the deposit and dissemination of scientific research documents, whether they are published or not. The documents may come from teaching and research institutions in France or abroad, or from public or private research centers.
L'archive ouverte pluridisciplinaire HAL, est destinée au dépôt et à la diffusion de documents scientifiques de niveau recherche, publiés ou non, émanant des établissements d'enseignement et de recherche français ou étrangers, des laboratoires publics ou privés. 


\title{
Structural and luminescent properties of homoleptic
}

\author{
silver(I), gold(I) and palladium(II) complexes with
}

\section{$n \mathrm{NHC}-t z \mathrm{NHC}$ heteroditopic carbene ligands}

\author{
Marco Monticelli, Marco Baron, Cristina Tubaro, ${ }^{*}$ Stéphane Bellemin-Laponnaz, ${ }^{*}$ Claudia \\ Graiff, Gregorio Bottaro, "Lidia Armelao*\| Laura Orian
}

Dipartimento di Scienze Chimiche, Università degli Studi di Padova, via F. Marzolo 1, 35131 Padova, Italy.

Institut de Physique et Chimie des Matériaux de Strasbourg (IPCMS), CNRS-Université de Strasbourg UMR7504, 23 rue du Loess BP 43, 67034 Strasbourg, France.

• Dipartimento di Scienze Chimiche, della Vita e della Sostenibilità Ambientale, Università degli Studi di Parma, Parco Area delle Scienze 17/A, 43124 Parma, Italy.

|| Istituto di Chimica della Materia Condensata e di Tecnologie per l'Energia, ICMATE-CNR, via Marzolo 1, 35131 Padova, Italy.

ABSTRACT: Novel silver(I), gold(I) and palladium(II) complexes were synthesized with bidentate heteroditopic carbene ligands that combine an imidazol-2-ylidene ( $n \mathrm{NHC}$ ) with a 1,2,3-triazol-5ylidene ( $t z \mathrm{NHC})$ connected by a propylene bridge. The silver(I) and gold(I) complexes were dinuclear species, $\left[\mathrm{M}_{2}(n \mathrm{NHC}-t z \mathrm{NHC})_{2}\right]\left(\mathrm{PF}_{6}\right)_{2}(\mathrm{M}=\mathrm{Ag}$ or $\mathrm{Au})$, with the two bidentate ligands bridging the metal centers, whereas in the palladium(II) complex $\left[\mathrm{Pd}(n \mathrm{NHC}-t z \mathrm{NHC})_{2}\right]\left(\mathrm{PF}_{6}\right)_{2}$, the two ligands 
were chelated on the same metal center. Because of the presence of two different carbene units, isomers were observed for the gold(I) and palladium(II) complexes. The molecular structures of the head-to-tail isomer for gold(I) complexes, both with a twisted or folded-syn conformation of the bridge between the carbene units, were determined by X-ray diffraction analysis. The study was completed with a systematic structural investigation through DFT calculations. For palladium(II) species, the head-to-head form was structurally characterized. The dinuclear gold(I) complexes were emissive in the solid state in the blue region (PLQY up to $8 \%$ ); time dependent density functional theory (abbreviated as TD-DFT) calculations disclosed that the absorption bands have MLCT character and evidenced that the emission occurs from $\mathrm{T}_{1}$ level (phosphorescence).

KEYWORDS: N-heterocyclic carbenes; dinuclear complexes; heteroditopic ligands; blue luminescence; relativistic TD-DFT calculations. 


\section{INTRODUCTION}

Since the isolation of the first imidazol-2-ylidene in early 90 's, the interest of the scientific community towards N-heterocyclic carbenes (NHCs) has continuously increased. Nowadays, NHCs are employed as efficient organocatalysts, ${ }^{23}$ although their main use remains as ligands for transition metal centers ${ }^{4.9}$ and the resulting NHC-complexes have found application in several research areas, i.e. catalysis, bioinorganic chemistry and material science ${ }^{4.10-13}$ Also bidentate di-NHCs have received quite a bit of attention, ${ }^{14-16}$ especially considering that, in this latter case, it is possible to tune the stereo-electronic properties of the ligand by changing the wingtip and backbone substituents of the heterocyclic ring, but also by modifying the linker between the carbene units. Furthermore, the nature of the bridge between the heterocyclic moieties can be a key element in influencing the bridging rather than chelating coordination mode of the ligand to the metal centers: with short or constrained linkers; a bridging coordination of the ligand between different metals gives polynuclear structures, while with more flexible bridges, the chelating coordination occurs preferentially. ${ }^{1718}$ The majority of the examples reported in the literature regards di-NHC based on two imidazol-2-ylidene rings $(n \mathrm{NHC})$ connected by an aliphatic or aromatic bridge; however, several heterocyclic scaffolds are available to prepare heterocyclic carbenes, spanning from the classical imidazole-, imidazoline- or benzimidazole-ylidene to other five-member rings, like pyrazole-, triazole- or tetrazole-ylidene, to six-, seven- or four-member rings or to more exotic ones. ${ }^{1920}$ Among them, it is interesting to mention the 1,3,4-trisubstituted-1,2,3-triazol-5-ylidene compounds $(t z \mathrm{NHC})$, whose triazolium salt precursors can be easily isolated via a click reaction, i.e. the copper-catalyzed alkyne azide cycloaddiction (CuAAC), followed by the alkylation of the nitrogen in N-3 position. ${ }^{21}$ The synthesis of heteroditopic carbene ligands, i.e. ligands combining two types of N-heterocyclic carbenes, is appealing because, in principle, it should allow to isolate original heterobimetallic species, taking advantage of the different acidity of the heterocyclic rings ${ }^{22-25}$ Moreover, the properties of a complex having a bidentate ligand with mixed donors might not be intermediate with respect to those of the corresponding homo-ditopic compounds. For 
example, a palladium(II) complex with a dicarbene ligand having two different NHC donors was found to display enhanced catalytic properties with respect to the corresponding complexes with the homo-dicarbene ligands; this was explained in terms of "electronic asymmetry" in the complex. ${ }^{2627}$

In this work, the influence of a mixed $n$ NHC- $t z$ NHC dicarbene ligand was evaluated on the photoemission properties of the corresponding dinuclear silver(I) and gold(I) complexes. The employed ligands were designed with a propylene linker between the $n \mathrm{NHC}$ and the $t z \mathrm{NHC}$ donors, because we demonstrated that this bridge has the right length and flexibility to promote intramolecular metallophilic interactions, thus influencing the luminescence properties ${ }^{28}$ and the reactivity of the gold(I) complexes. ${ }^{29}$ The coordination of these mixed dicarbenes was also extended to a palladium(II) complex, which, compared to the gold(I) complexes, should present a different coordination geometry (square planar vs. linear) and a chelate coordination of the ligand, rather than a bridging one. The synthesis of the gold(I) and palladium(II) complexes was readily achieved through transmetalation of the dicarbene ligand from the corresponding silver(I) complexes. Interestingly, in the case of homobimetallic gold(I) complexes, as well as for the mononuclear palladium(II) complex, two isomers were observed in solution. For gold(I) complexes, the luminescence properties as well as the nature of the different possible isomers were investigated through relativistic DFT and TD-DFT calculations.

\section{RESULTS AND DISCUSSION}

Synthesis of the imidazolium-triazolium proligands. Two different proligands with imidazolium and 1,2,3-triazolium rings, connected by a propylene bridge, were successfully synthesized following the procedure reported by Liebscher and described in Scheme $1 .^{30.31}$

The procedure involves three steps from 1-(pent-4-ynyl)-1H-imidazole: i) formation of the triazole ring via the CuAAC reaction, ii) methylation of both the imidazole $\mathrm{N} 3$ and triazole $\mathrm{N} 1$ nitrogen atoms using excess of methyl iodide, providing 1-I and 2-I, iii) anion exchange between I and $\mathbf{P F}_{6}$, to give $\mathbf{1}-\mathbf{P F}_{6}$ and $\mathbf{2}-\mathbf{P F}_{6}$. The last step favors the solubility of the proligands in polar 
solvents (DMSO and mostly $\mathrm{CH}_{3} \mathrm{CN}$ ). The formation of the desired imidazolium/triazolium salt was easily assessed by the ${ }^{H} \mathrm{H}$ NMR spectra, which present two different signals located at $\delta>8.0$ ppm attributable to the protons in position 2 of the imidazolium moiety and in position 5 of the triazolium ring.

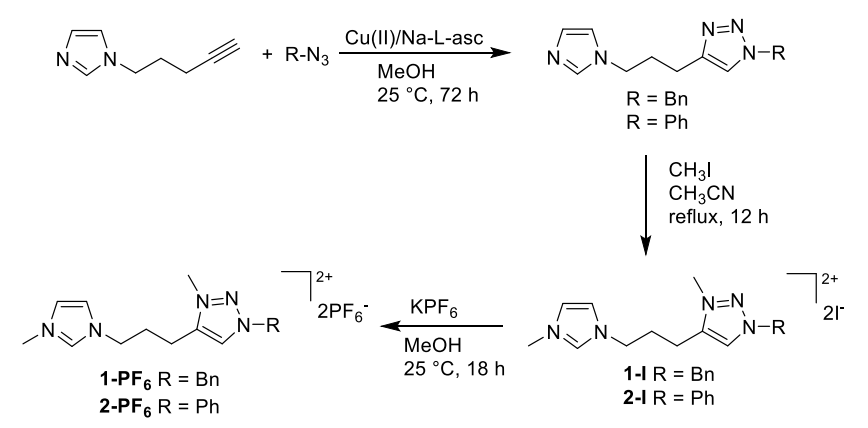

Scheme 1. Synthesis of the proligands $\mathbf{1}-\mathbf{P F}_{6}$ and $\mathbf{2}-\mathbf{P F}_{6}$.

Synthesis of silver(I) complexes. The silver(I) di(N-heterocyclic carbene) complexes 3 and 4 were synthesized by reaction of the proper diazolium bis(hexafluorophosphate) salt, 1-PF 6 and 2$\mathbf{P F}_{6}$ respectively, with excess of silver(I) oxide in acetonitrile at $85^{\circ} \mathrm{C}$ for 48 hours (Scheme 2).

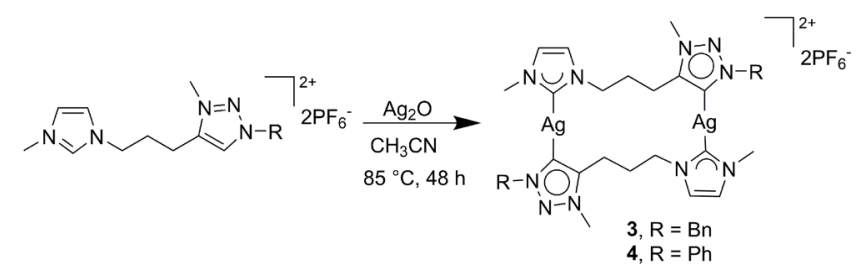

Scheme 2. Synthesis of silver(I) complexes $\mathbf{3}$ and $\mathbf{4}$

Complex 4 was obtained as a stable off-white solid, while complex $\mathbf{3}$, although spectroscopically pure, is an oil that slowly decomposes. The disappearance of the signals at $\delta$ above $8.0 \mathrm{ppm}$ in the' $\mathrm{H}$ NMR spectra is consistent with the deprotonation at the positions $\mathrm{C} 2-\mathrm{H}$ of the imidazole moiety and $\mathrm{C} 5-\mathrm{H}$ of the triazole ring. In the ${ }^{13} \mathrm{C}$ NMR spectra, two different signals are present at $\delta \mathrm{ca} .165 \mathrm{ppm}$ 
and ca. $180 \mathrm{ppm}$, attributable to the carbene carbons of the $t z \mathrm{NHC}-\mathrm{Ag}$ and $n \mathrm{NHC}-\mathrm{Ag}$ moieties respectively, in the typical range reported in the literature. ${ }^{32}$ Finally, the presence of the peak corresponding to the fragment $\left[\mathrm{Ag}_{2} \mathrm{~L}_{2} \mathrm{PF}_{6}\right]^{+}$in the ESI-MS spectra confirms the dinuclear dicationic structure of the complexes, with the experimental isotopic distribution in agreement with the simulated one. All these data suggest a dinuclear structure for the silver complexes, with the two dicarbene ligands bridging two different silver(I) centers; the structure with an $n \mathrm{NHC}$ facing a $t z \mathrm{NHC}$ appears the most probable by analogy with related complexes reported in the literature, ${ }^{33}$ although a dynamic behavior in solution involving more than one isomer cannot be excluded.

Synthesis of gold(I) complexes. Gold(I) complexes were synthesized via two methods: i) transmetalation of the dicarbene ligand from the corresponding silver(I) complexes $\mathbf{3}$ and $\mathbf{4}$ using a Au:Ag 1:1 ratio, or ii) deprotonation of the diazolium salt with sodium acetate in the presence of the gold(I) precursor $\mathrm{AuCl}\left(\mathrm{SMe}_{2}\right)$. The transmetalation procedure was employed starting from both silver(I) complexes (Scheme 3), although with the ligand having benzyl substituent at the triazole ring the reaction was performed in situ, i.e. without the pre-isolation of silver(I) complex $\mathbf{3}$, considering its oily nature and instability. For these reasons, the gold(I) species, analogous to silver(I) complex $\mathbf{3}$, was also synthesized via deprotonation of the diazolium salt (Scheme 4).

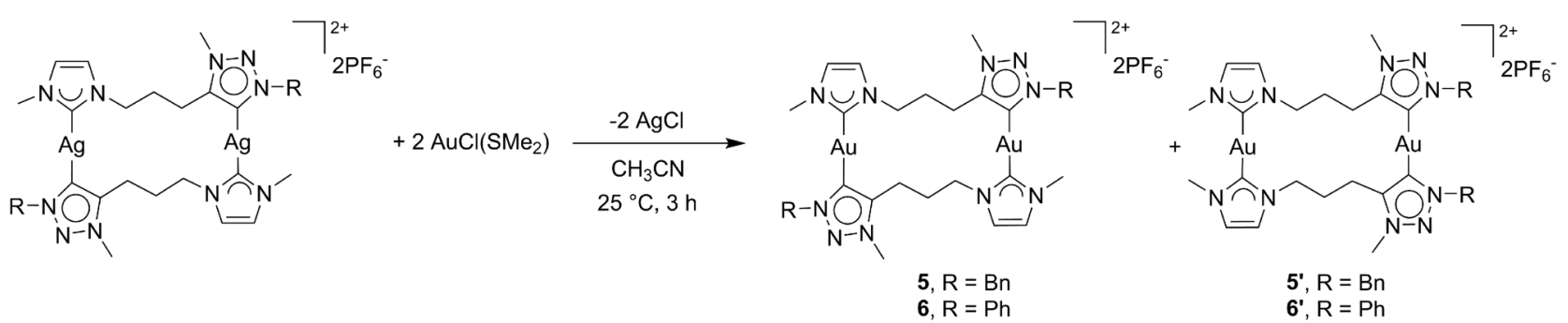

Scheme 3. Synthesis of gold(I) complexes 5/5' and 6/6'. 


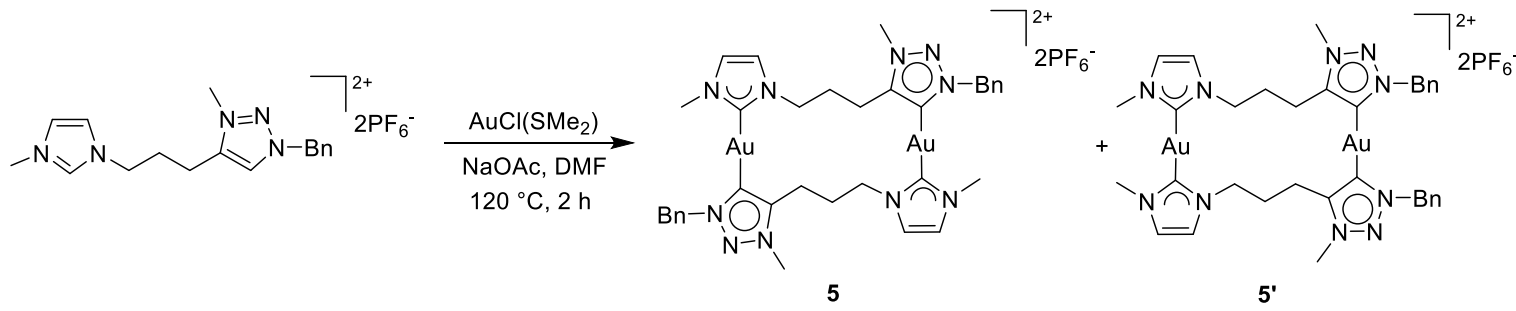

Scheme 4. Synthesis of gold(I) complexes 5/5'.

Interestingly, the NMR experiments of the isolated solids via transmetalation show two sets of signals in a close to $1: 1$ ratio, both in the ${ }^{\mathrm{H}} \mathrm{H}$ and in ${ }^{13} \mathrm{C}$ NMR spectra, likely due to the presence of the two isomers associable to the different coordination mode of the heteroditopic ligands. An analogous result was also obtained from the deprotonation reaction starting of the diazolium salt, although the observed ratio was 5:1 (complex $\mathbf{5}$ as major isomer). This difference in the molar ratio registered in the two synthetic procedures can be ascribed to the different reaction temperature, ${ }^{34}$ which should favor the formation of the most stable isomer.

Due to the intrinsic ditopic nature of the ligands and the possible orientations of the propylene linker in the ligand, several isomers could be figured out. The main difference regards the coordination sphere around the metal centers (constitutional isomerism, Chart 1, a): i) in the headto-tail species, each gold(I) center is coordinated by one $n \mathrm{NHC}$ and one $t z \mathrm{NHC}$, ii) in the head-tohead species, one gold(I) coordinates two $n \mathrm{NHC}$ and the other one binds the two $t z \mathrm{NHC}$. We labeled the crude mixture of complexes $\mathbf{5 / 5}$ ' and $\mathbf{6 / 6}$ ' where the apostrophe indicates the head-tohead isomer. Furthermore, considering the possible arrangements of the bridge of bidentate ligand, these two coordination isomers may be present at least in four conformations (conformational isomerism): the twisted ( $\mathrm{t})$, the folded-syn ( $\mathrm{f} s)$, the folded-anti $(\mathrm{f} a$ ) and the stretched-out ones (s) (Chart $1, \mathrm{~b})$ represented only for the head-to-tail coordination). 
(a)

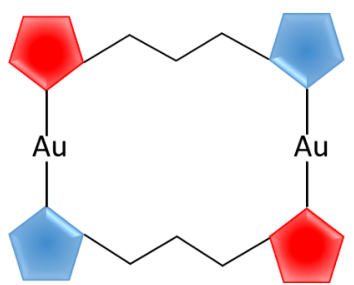

head-to-tail

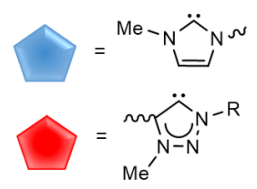

$\mathrm{R}=\mathrm{Bn}$ or $\mathrm{Ph}$

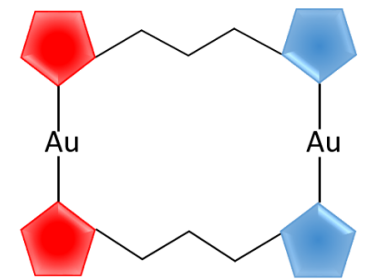

head-to-head

(b)

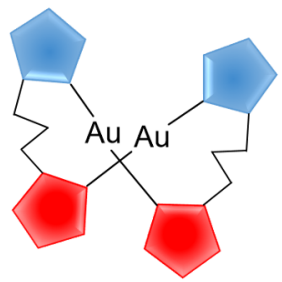

head-to-tail twisted (t)

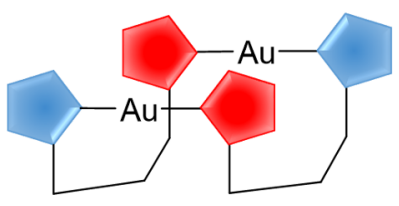

head-to-tail folded-syn (fs)

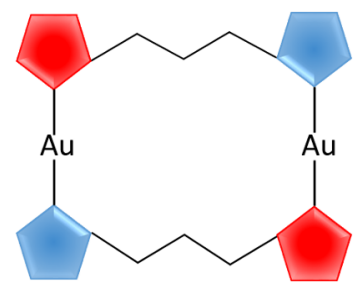

head-to-tail stretched-out (s)

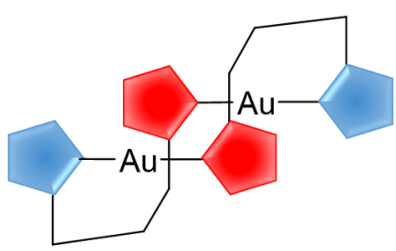

head-to-tail folded-anti (fa)

Chart 1. Schematic representation of the possible isomers for the gold(I) dinuclear complexes: (a) head-to-head and head-to-tail constitutional isomers and (b) the conformational isomers (twisted, folded-syn, folded-anti and stretched-out) represented only for the head-to-tail coordination.

From this point of view, the two sets of signals might be associated to two species differing for the arrangement of the bridge in the bidentate ligands ${ }^{34,35}$ (conformational isomerism) or for the headto-head or head-to-tail coordination (constitutional isomerism). In our opinion, the latter appears more convincing considering that i) the 'H NMR spectrum registered after heating the solution of the mixture 6/6' at $70{ }^{\circ} \mathrm{C}$ in a NMR tube remains unchanged and also the relative ratio of the two set of signals remains constant; if the two species differ for the conformation of the bridge, upon increasing the temperature a conversion or an exchange between the two species is expected, considering the flexibility of the propylene linker. The unchanged spectra support indirectly the presence of two constitutional isomers, that cannot convert upon heating. ii) the different conformations of the bridges might not be retained in solution; ${ }^{36}$ iii) a similar $\operatorname{di}(n \mathrm{NHC}) \operatorname{gold}(\mathrm{I})$ complex, i.e. $\left[\mathrm{Au}_{2}\left(\mathrm{MeIm}\left(\mathrm{CH}_{2}\right)_{3} \mathrm{ImMe}\right)_{2}\right]^{2+} \quad(\mathrm{Im}=$ imidazole-2-ylidene $)$, presents the same NMR 
spectrum profile in the folded-syn or twisted conformation (Chart 1b); ; $237^{2 i v}$ ) starting from the mixture 6/6' we were able to crystallize complex 6 (head-to-tail coordination of the ligand with folded-syn conformation of the bridges, see further in the text) and characterized it in solution. Complex $\mathbf{6}$ is stable in solution and no conversion to the second species was observed; furthermore, the H-NMR analysis of the remaining solution, where the crystals were grown, confirmed an increased of the $6 \% / 6$ ratio, thus supporting the presence of two different species like two constitutional isomers are; v) during a slightly modified synthesis, the head-to-head isomeric form was isolated by crystallization (see below and the structure of complex 7).

The formation of the gold(I) complexes could be confirmed by the presence of signals at ca. $\delta$ 170 and $185 \mathrm{ppm}$ related to the carbene carbons in position 2 and 5 of the $n \mathrm{NHC}$ and $t z \mathrm{NHC}$ respectively, slightly downfield shifted from those observed for the related silver(I) complexes and in the range of ppm reported in the literature for $n \mathrm{NHC}$ and $t z \mathrm{NHC}$ gold(I) complexes. ${ }^{32.38}$ The dinuclear dicationic structure of complexes $\mathbf{5 / 5}$ ' and 6/6' was confirmed by ESI-MS spectra which present a signal attributed to the species $\left[\mathrm{Au}_{2} \mathrm{~L}_{2} \mathrm{PF}_{6}\right]^{+}$with $\mathrm{L}=n \mathrm{NHC}-t z \mathrm{NHC}$ dicarbene ligand.

By slow diffusion of diethyl ether into a solution of the mixtures $\mathbf{5 / 5}$ ' and $\mathbf{6 / 6} \mathbf{6}^{\prime}$ in acetonitrile, few crystals were obtained and the molecular structure of the crystallized compound was determined by X-ray diffraction. In both cases, i.e. starting from mixtures $\mathbf{5 / 5}^{\prime}$ or $\mathbf{6}^{\prime} \mathbf{6}^{\prime}$, only crystals of the head-totail isomer were isolated. Complexes $\mathbf{5}$ and $\mathbf{6}$ have a dinuclear dicationic nature with two dicarbene ligands bridging the two gold atoms and the two gold(I) centers are coordinated to one $t z \mathrm{NHC}$ and one $n \mathrm{NHC}$. 


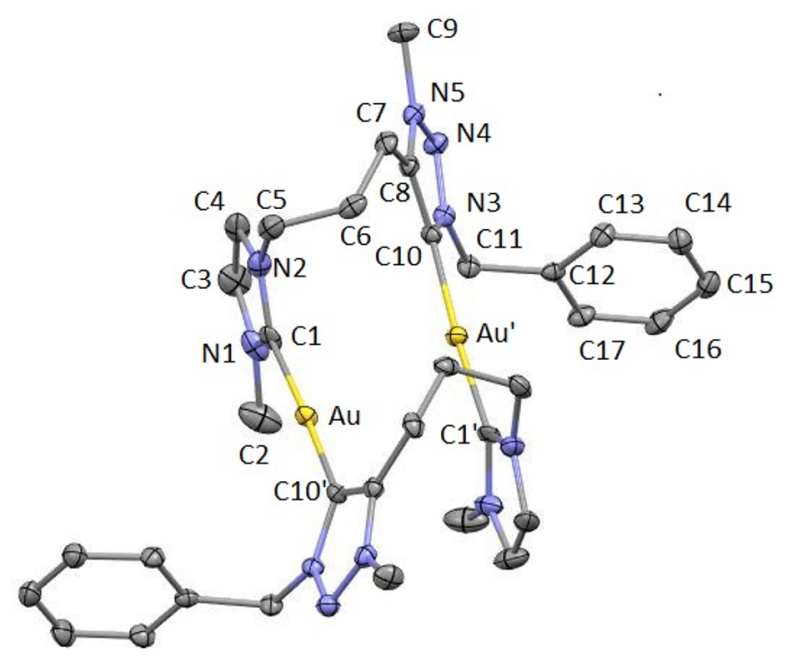

Figure 1. ORTEP-style view of the cationic compound $\mathbf{5}(\mathbf{f} s)$, with atomic numbering scheme; ellipsoids are drawn at their $30 \%$ probability level. Hydrogen atoms and $\mathrm{PF}_{6}$ anions have been omitted for clarity. Selected bond distances $(\AA)$ and angles $\left(^{\circ}\right)$ : C1-N2 1.349(9), C1-N1 1.371(7), C1-Au 2.005(5), C8-C10 1.397(6), C10-N3 1.371(6), C10'-Au 2.026(5), Au'*Au' 3.3479(4), N3N4 1.316(7), N4-N5 1.325(6); N2-C1-N1 103.0(5), N2-C1-Au 127.9(4), N1-C1-Au 129.0(5), N3C10-C8 102.0(4), N3-C10-Au’ 124.1(3), C8-C10-Au’ 133.3(4), C1-Au-C10’176.1(2), C1-Au-Au’ 71.47(15), C10'-Au-Au' 111.71(14). Code for atoms: ‘ =-x, y, 0,5-z. 


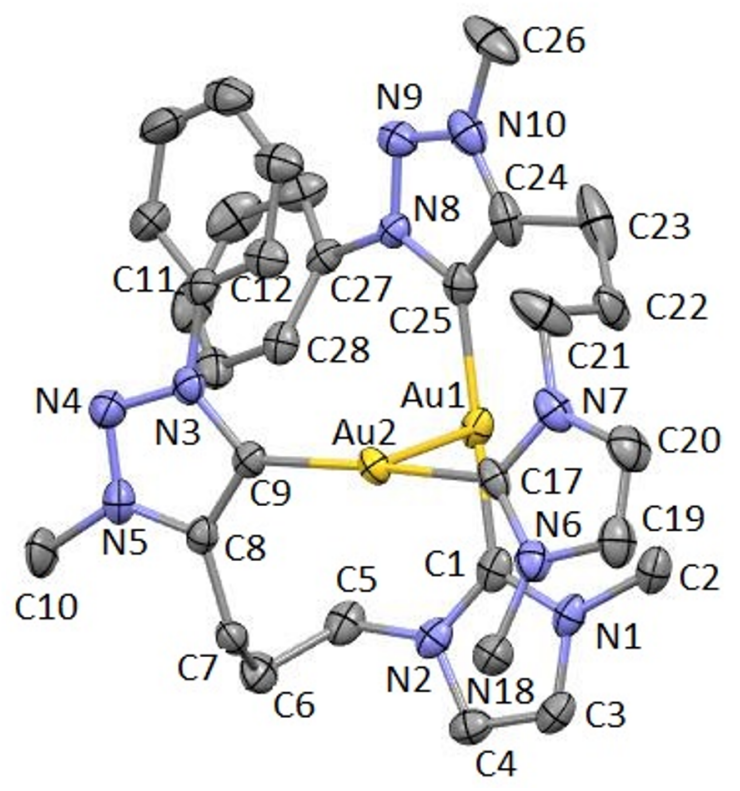

Figure 2. ORTEP-style view of the cationic compound $\mathbf{6}(\mathbf{t})$, with atomic numbering scheme; ellipsoids are drawn at their $30 \%$ probability level. Hydrogen atoms and $\mathrm{PF}_{6}$ anions have been omitted for clarity. Selected bond distances $(\AA)$ and angles $\left(^{\circ}\right)$ : Au1-C1 2.020(10), Au1-C25 2.040(10), Au1-Au2 3.0680(5), Au2-C9 2.020(9), Au2-C17 2.012(9), N1-C1 1.365(11), N2-C1 1.331(12), N3-N4 1.351(10), N4-N5 1.330(11), N6-C17 1.365(12), N7-C17 1.357(11), N8-N9 1.331(10), N9-N10 1.305(11); C1-Au1-C25 176.7(3), C1-Au1-Au2 82.8(2), C25-Au1-Au2 94.5(2), C9-Au2-C17 175.5(3), C9-Au2-Au1 89.3(2), C17-Au2-Au1 94.6(2).

The ORTEP views of the cationic complexes are shown in Figures 1 and 2 together with the atomic numbering scheme. Relevant bond distances and angles are reported in the captions. The flexible propylene linkers allow a backfolded conformation of the bridges in both structures, ${ }^{39}$ however, in complex 5, they adopt the folded-syn conformation ( $\mathrm{f} s$, Chart $1 \mathrm{~b}$ ), , while in compound 6 the observed conformation is the twisted one ( $t$, Chart 1). From this point onwards, also the arrangement of the bridge will be specified in the notation of the complex. In the crystals of the cationic compound $\mathbf{5}(\mathbf{f} s), \mathrm{PF}_{6}$ anions are present, while in those of $\mathbf{6}(\mathbf{t})$, acetonitrile solvent molecules are also found. Both cationic complexes present a dinuclear structure, with the two 
gold(I) centers linearly dicoordinated, a geometry usually observed for metal centers having a $\mathrm{d}^{10}$ electronic configuration. The bond angles $\mathrm{C}_{\text {cath }}-\mathrm{Au}-\mathrm{C}_{\text {cat }}$ are close to the linearity $\left[176.1(2)^{\circ}\right.$ in $\mathbf{5}(\mathbf{f} s)$ and $176.7(3)$ and $175.5(3)^{\circ}$ in $\mathbf{6}(\mathbf{t})$ ] and the bond distances are comparable with those reported for analogous di(NHC) gold(I) complexes..$^{28,40}$ The torsion angle $\mathrm{C}_{\text {casb }}-\mathrm{Au} \cdots \mathrm{Au}-\mathrm{C}_{\text {cato }}$ in $\mathbf{5}(\mathbf{f s})$ is $20.2(1)^{\circ}$, while in $\mathbf{6}(\mathbf{t})$ is close orthogonal $\left[79.0(4)\right.$ and $\left.83.1(4)^{\circ}\right]$. Moreover the $\mathrm{C}_{\text {aat }}-\mathrm{Au} \cdots \mathrm{Au}$ angle is close to orthogonal in $\mathbf{6}(\mathbf{t})$ [89.3(2), 94.5(2), 94.6(2), 82.8(2) ${ }^{\circ}$ and bigger than $90^{\circ}$ in $\left.\mathbf{5 ( f s}\right)\left[111.7(1)^{\circ}\right]$. This affects the $\mathrm{Au} \cdots \mathrm{Au}$ separation which is significantly different in the two complexes: in 5(fs), the gold atoms are separated by 3.3479(4) $\AA$, while in $\mathbf{6 ( t )}$, the 3.0680(5) $\AA$ gold to gold distance, being much below the sum of the Van der Waals radii for gold metal, is one of the shortest ever observed in analogous di(NHC) gold(I) complexes so far. ${ }^{40}$ This clearly suggests the presence of aurophilic interaction between the two metals. In both structures, the mean plane of the two imidazol rings coordinated to the same Au atom are slightly twisted, being the dihedral angle $30.8(1)^{\circ}$ in $\mathbf{5 ( f s )}$ and 18.6(1) and $17.7(1)^{\circ}$ in $\mathbf{6}(\mathbf{t})$, respectively. In the molecular and crystal structures of $\mathbf{5}(\mathbf{f} s)$ and $\mathbf{6}(\mathbf{t})$, no stacking is observed between the planar ring moieties, except between the phenyl and triazole rings in $\mathbf{6}(\mathbf{t})$ labeled by atoms $\mathrm{C} 11, \mathrm{C} 12, \mathrm{C} 13, \mathrm{C} 14, \mathrm{C} 15, \mathrm{C} 16$ and $\mathrm{N} 8, \mathrm{~N} 9, \mathrm{~N} 10, \mathrm{C} 24, \mathrm{C} 25$ (evidenced in Figure 3 by the ball and stick drawing). In fact, these groups lie on almost parallel planes [dihedral angle of $8.1(4)^{\circ}$ ] at a distance between the centroids of the rings of 3.764(6) $\AA$. The bridging coordination mode of the dicarbene ligands imposes coordination chirality to complex $\mathbf{6}(\mathbf{t})$. Nevertheless, the complex crystallizes in $C 2 / c$ space group and so both enantiomers are present in the crystals. 


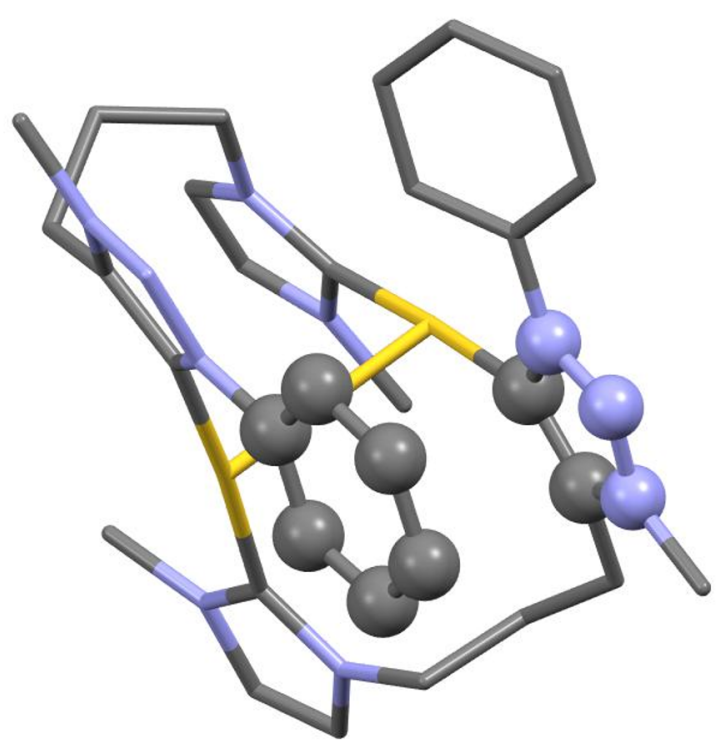

Figure 3. View of the cationic part of complex $\mathbf{6}(\mathbf{t})$, emphasizing the parallel planes of the phenyl ring and the triazole one. 


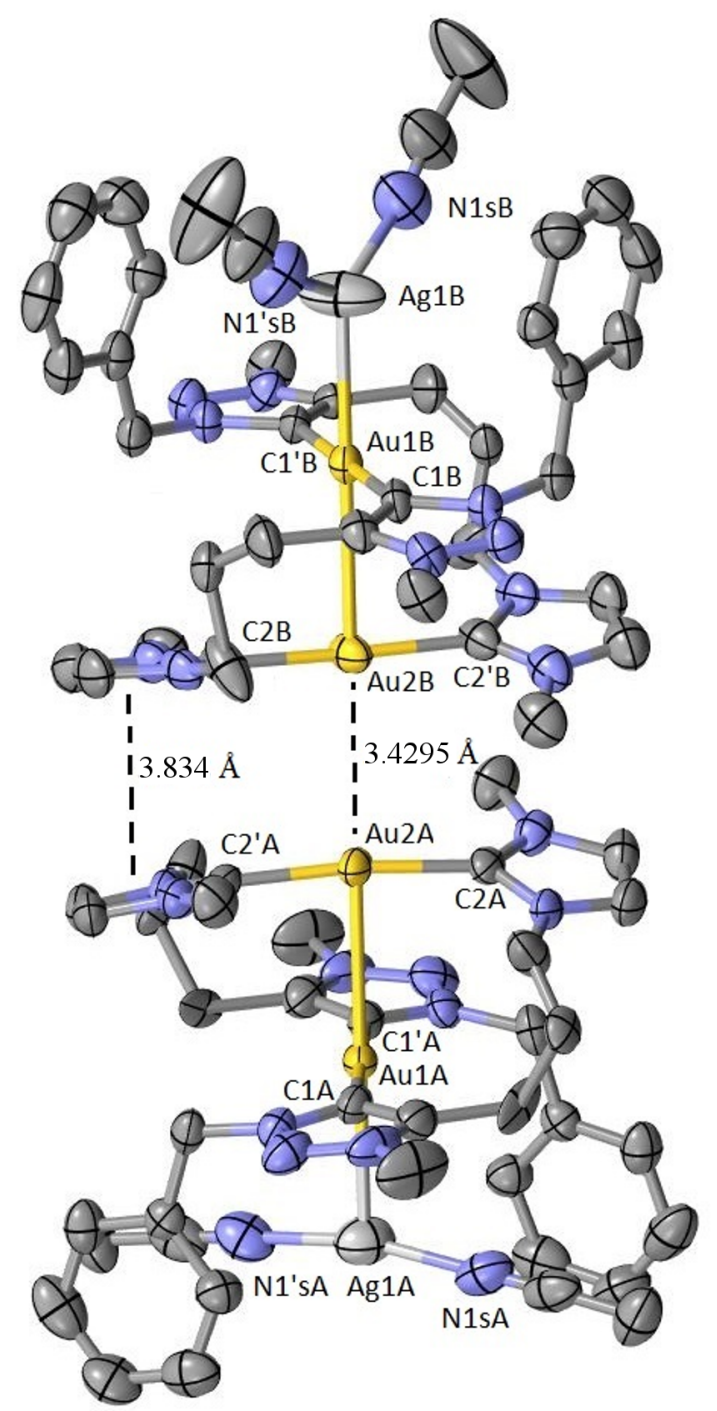

Figure 4. ORTEP-style view of cationic compound 7 [molecule A (bottom) and B (top)], with selected atomic numbering scheme; ellipsoids are drawn at their $30 \%$ probability level. Hydrogen atoms have been omitted for clarity. Selected bond distances $(\AA)$ and angles $\left(^{\circ}\right)$ : C2A-Au2A 2.020(9), C1A-Au1A 2.002(11), C2B-Au2B 2.025(11), C1B-Au1B 2.028(9), N1SB-Ag1B 2.157(14), N1SA-Ag1A 2.085(13), Au1B-Ag1B 2.7165(18), Au1B-Au2B 3.0516(8), Au2A-Au1A 3.1195(8), Au1A-Ag1A 2.8860(16); C1B-Au1B-C1'B 179.5(5), C1B-Au1B-Ag1B 89.7(3), C1BAu1B-Au2B 90.3(3), C2B-Au2B-C2'B 178.1(5), C2B-Au2B-Au1B 89.0(3), C2A-Au2A-C2'A 173.7(5), C2A-Au2A-Au1A 86.8(2), C1A-Au1A-C1'A 178.8(5), C1A-Au1A-Ag1A 89.4(3), C1A- 
Au1A-Au2A 90.6(3), N1SA-Ag1A-N1'SA 167.3(6), N1SB-Ag1B-N1'SB 129.6(8). Code for atoms: ' $=1-\mathrm{x}, \mathrm{y}, 1.5-\mathrm{z}$

As stated above, the gold complexes $\mathbf{5 / 5}$, were synthesized without isolation of the silver complex, and, in particular, the gold precursor $\mathrm{AuCl}\left(\mathrm{SMe}_{2}\right)$ was simply added to the acetonitrile solution of the silver complex $\mathbf{3}$, once filtered from the silver oxide in excess. In one of the first attempts to synthesize the gold complexes, we performed the same reaction but adding the gold(I) precursor directly to the reaction mixture, still containing the silver oxide. By slow diffusion of diethyl ether in the final acetonitile solution, very few single crystals of 7, adequate for X-ray diffraction analysis were formed. In the crystals of 7, two slightly different molecules of trinuclear bimetallic compounds (molecule A and molecule B) of formula $\left[\mathrm{Au}_{2}(n \mathrm{NHC}-t z \mathrm{NHC})_{2} \mathrm{Ag}\left(\mathrm{CH}_{3} \mathrm{CN}\right)_{2}\right]^{3+}$, $\mathrm{PF}_{6}$ anions and diethyl ether molecules are present. The crystal structure of the two cationic compounds is shown in Figure 4, together with a selected atomic labeling scheme. Relevant bond distances and angles of the two molecules are also reported in the caption. The trinuclear compounds are composed of two gold and one silver metal atoms; interestingly, the two gold atoms are linked by two head-to-head ligands in a twisted conformation and the fragment $\operatorname{Ag}\left(\mathrm{CH}_{3} \mathrm{CN}\right)_{2}$ is interacting to one of the two $\mathrm{Au}$ centers. The $\mathrm{Ag}\left(\mathrm{CH}_{3} \mathrm{CN}\right)_{2}$ fragment in the two molecules presents different geometrical parameters: in fact, in molecule A, the two acetonitrile molecules are disposed in a nearly linear mode $\left(\mathrm{N}-\mathrm{Ag}-\mathrm{N}\right.$ bond angle $\left.167.3(6)^{\circ}\right)$, while, in molecule $\mathrm{B}$, the same fragment presents a nearly trigonal planar arrangment $\left(\mathrm{N}-\mathrm{Ag}-\mathrm{N}\right.$ bond angle $\left.129.6(8)^{\circ}\right)$. This affects also the $\mathrm{Ag} \cdots \mathrm{Au}$ distance which is longer in molecule A $(2.8860(16) \AA)$ than in molecule B $(2.7165(18) \AA$ ). The $\mathrm{Au} \cdots \mathrm{Au}$ distances (3.1195(8) $\AA$ and 3.0516(8) $\AA$ for molecule A and B, respectively) are very similar in both complexes and in agreement with the values measured in analogous bimetallic dicarbene gold(I) complexes. ${ }^{28373941}$ The two molecules are adjacent in the crystal structure with terminal Au2 atoms at a distance of 3.4295(7) $\AA$. Moreover, the imidazole rings of the ligands are 
stacked in almost parallel planes (dihedral angle of $9.6(5)^{\circ}$ ) and the distance between the centroids is 3.834(6) $\AA$. The $\mathrm{Au}$ and $\mathrm{Ag}$ atoms of both molecules are aligned on the same two-fold crystallographic axis. Thus, the complexes are symmetric, being one half of both structures correlated with the other half by the two-fold axis. A disordered diethyl ether molecule separates the two stacked molecules. In both molecules, the benzyl substituents of the bridging ligands point towards the $\mathrm{Ag}\left(\mathrm{CH}_{3} \mathrm{CN}\right)_{2}$ fragment to minimize the steric hindrance. The imidazole rings coordinated to the same $\mathrm{Au}$ atom $(\mathrm{Au} 2 \mathrm{~A}$ and $\mathrm{Au} 2 \mathrm{~B})$ are slightly twisted with a dihedral angle of 34.3(6) and $29.7(16)^{\circ}$, while the triazole rings coordinated to the same $\mathrm{Au}$ atom (Au1A and Au1B) are almost coplanar $\left[8.7(1)\right.$ and $\left.8.8(6)^{\circ}\right]$.

Luminescence properties. The photoluminescence properties of silver(I) complex $\mathbf{4}$ and gold(I) complexes $\mathbf{5}(\mathbf{f s})$ and $\mathbf{6}(\mathbf{t})$, the isomers isolated by crystallization, were analyzed at room temperature in the solid state as films obtained by drop casting from acetonitrile solutions on quartz substrate. The silver complex 4 was found to be non-emissive and a darkening of the sample was observed after the analysis, consistently with the known sensitivity of silver compounds to light exposure. Both gold complexes displayed instead intense blue luminescence (Figure 5). The emission maximum of $\mathbf{5}(\mathbf{f s})$, centered at $430 \mathrm{~nm}$, is blue-shifted of $50 \mathrm{~nm}$ with respect to that of $\mathbf{6}(\mathbf{t})$. We observed comparable absolute emission quantum yields with maximum value of $8 \%$ for $\mathbf{6}(\mathbf{t})$ that has also the shorter $\mathrm{Au} \cdots \mathrm{Au}$ distance (3.068 $\AA$, Table 1). This suggests a stronger aurophilic interaction than for $\mathbf{5}(\mathbf{f s})$. 

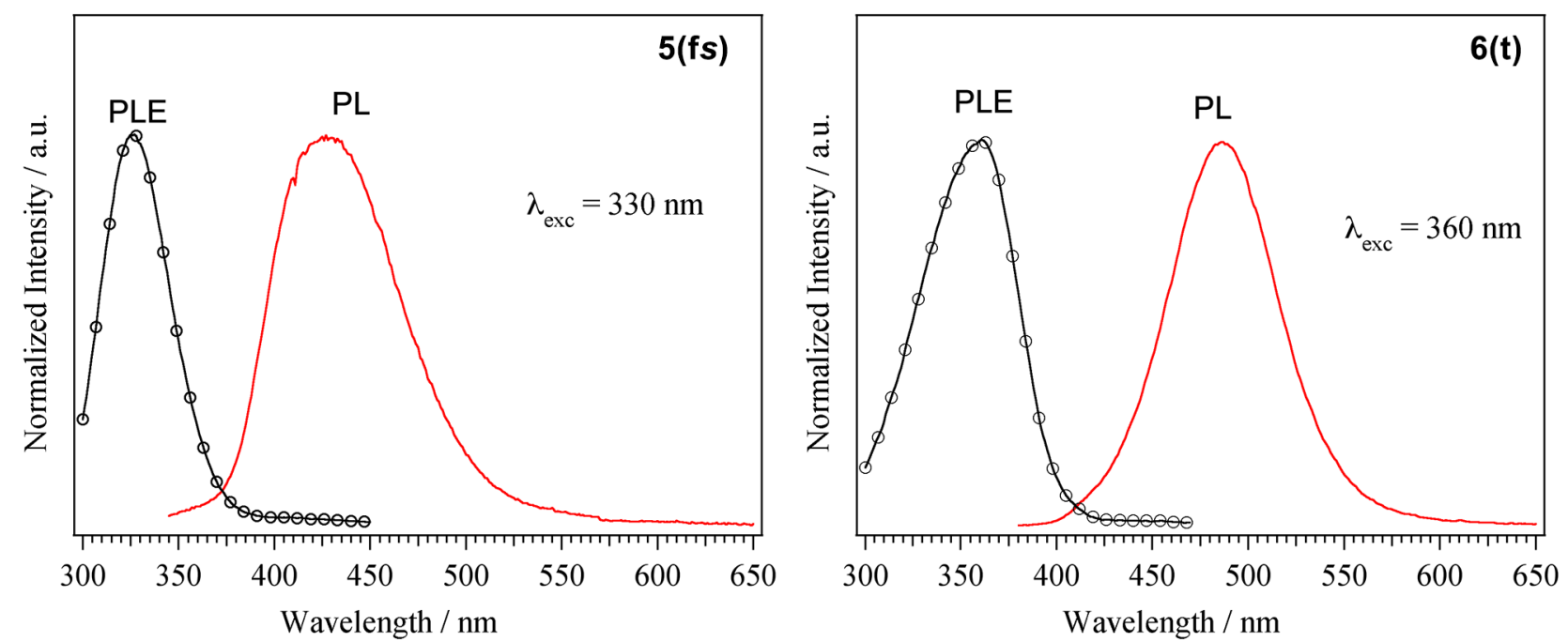

Figure 5. Solid-state excitation (PLE, line and symbol) and emission (PL, red line) spectra of complexes $\mathbf{5}(\mathbf{f s})$ (left) and $\mathbf{6}(\mathbf{t})$ (right).

The photoluminescence excitation spectra (PLE, Figure 5) are centered in the UV region with a low energy tail extending in the visible up to $c a .420 \mathrm{~nm}$ for $\mathbf{6}(\mathbf{t})$, and are attributed to metal to ligand transitions, as confirmed also by TD-DFT calculations of the lowest electronic absorption (see below). In the case of complex 6(t), PL and PLE bands are red-shifted relative to those of the corresponding diimidazolium salt $\mathbf{2}-\mathbf{P F}_{6}$ (Figure $\mathbf{S} 1$ ). This is mainly ascribed to the perturbation provided by coordination of the ligand to the metal centers. Instead, 1-PF 6 did not show appreciable luminescence. The emission decay curves of both $\mathbf{5}(\mathbf{f} s)$ and $\mathbf{6}(\mathbf{t})$ were interpolated with a threeexponential function, resulting in average lifetimes of 0.23 and $1.21 \mu \mathrm{s}$, respectively. 
Table 1. Photophysical data of the gold(I) complexes $\mathbf{5}(\mathbf{f} s)$ and $\mathbf{6}(\mathbf{t})$ in solid state at room temperature.

\begin{tabular}{llllll}
\hline & Excitation & Emission & $\Phi(\%)^{\mathrm{a}}$ & $\tau(\mu \mathrm{s})^{\mathrm{b}}$ & $\mathrm{Au} \cdots \mathrm{Au}$ distance $(\AA)$ \\
& $\lambda_{\text {max }}(\mathrm{nm})$ & $\lambda_{\text {max }}(\mathrm{nm})^{\mathrm{a}}$ & & & \\
\hline $\mathbf{5 ( f )})$ & 330 & 430 & 5 & 0.23 & 3.348 \\
$\mathbf{6 ( t )}$ & 360 & 480 & 8 & 1.21 & 3.068
\end{tabular}

a Excited at wavelength corresponding to the maximum of PLE spectra. ${ }^{\circ}$ The emission follows a three-component exponential decay; the reported $\tau$ is the average of the three values.

In the solid state, the emission wavelength can be correlated to the aurophilic interaction, which in turn depends on the $\mathrm{Au} \cdots \mathrm{Au}$ distance as found in the single-crystal X-ray diffraction studies. In fact, a stronger aurophilic contact is expected to lead to a lower emission energy. Accordingly, we observed the emission band of $\mathbf{6}(\mathbf{t})$ red-shifted compared to that of $\mathbf{5}(\mathbf{f s})$.

The emission properties of gold(I) complexes depend both on the extent of aurophilic interactions and molecular stacking in the lattice that can be tailored by the ligands thanks, for example, to the presence of supramolecular interactions. In this case, we did not observe the formation of particular supramolecular arrangements in the solid state: in the dinuclear complex $\mathbf{6}(\mathbf{t})$, the $\mathrm{Au} \cdots \mathrm{Au}$ distance (3.068 $\AA$ ) is indeed shorter than that observed in highly emissive samples (PLQY=96\%, $3.272 \AA$ ) having however a peculiar staggered arrangement in the unit cell.$^{28}$ The absence of similar spatial arrangement of the complexes in the crystals of $\mathbf{5}(\mathbf{f s})$ and $\mathbf{6}(\mathbf{t})$ could account for the moderate quantum yields registered for these complexes. These results further support the difficulty to foresee the extent of the luminescence of this type of complexes because several factors (aurophilicity, crystal packing, $\pi-\pi$ interactions,...) play a role preventing any a priori prediction.

DFT analysis. As described in the previous sections and in particular in the description of the single crystal structures, the dinuclear gold(I) complexes can differ not only for the coordination 
around gold (head-to-tail or head-to-head coordination of the heteroditopic ligand), but also for the relative orientation of the propylene bridges: twisted ( $\mathrm{t}$ ), folded-syn ( $\mathrm{f} s$ ), folded-anti ( $\mathrm{f} a$ ) and stretched-out (s) (Chart 1). Consequently, at least eight isomers might be obtained for each gold(I)gold(I) complex. First, we optimized the structures of the four possible conformers $(\mathrm{t}, \mathrm{f} s, \mathrm{f} a, \mathrm{~s})$ of the head-to-tail complex 6 at ZORA-BLYP/TZ2P level of theory (Figure S2a). For complex 6(t), the crystallographic coordinates were used as initial guess, while the remaining three conformers were built manually. The twisted and both the folded (syn and anti) conformers $(\mathbf{6}(\mathbf{t}), \mathbf{6}(\mathbf{f} s)$ and $\mathbf{6}(\mathbf{f} \boldsymbol{a}))$ are close in energy, differing by ca. $3 \mathrm{kcal} \mathrm{mol}^{-1}$, while the energy of the stretched-out $\mathbf{6}(\mathbf{s})$ is $11.3 \mathrm{kcal} \mathrm{mol}^{-1}$ higher than to the most stable one, $\mathbf{6}(\mathbf{t})$. Importantly, this last complex is also the one isolated by crystallization. Considering these results and the obtained crystal structures, reported in the previous section, the complexes 5, 5' and ' $'$ ' were also optimized at ZORA-BLYP/TZ2P level of theory, but considering only the twisted and folded-syn conformation of the bridges (Figure S2b). For 5(fs), the crystallographic coordinates were used as initial guess, while the other structures were built manually. The comparison between the computed and crystallographic structures reveals a nice agreement; the $\mathrm{Au}-\mathrm{Au}$ distance is only slightly overestimated. In all the complexes, the $\mathrm{Au}-\mathrm{Au}$ distance is in the range $3.01-3.29 \AA$. The position of the propylene bridges affects the overall geometry, since it imposes a more spherical shape, (twisted conformer) or a hemispherical shape (folded-syn species), leading to an antiparallel and almost parallel orientation of the C-Au-C axes, respectively. Notably, the shortest $\mathrm{Au}$-Au distances (3.01-3.17 $\AA$ ) are calculated for the twisted structures $\left[\mathbf{5}(\mathbf{t}), \mathbf{5}^{\prime}(\mathbf{t}), \mathbf{6}(\mathbf{t})\right.$ and $\left.\mathbf{6}^{\prime}(\mathbf{t})\right]$ and the longest ones $(3.24-3.31 \AA)$ in the remaining complexes. In general, the antiparallel orientation of the $\mathrm{C}-\mathrm{Au}-\mathrm{C}$ axes (twisted conformer) increases the stability of the complex; only $\mathbf{5}(\mathbf{f} s)$ lies $2.0 \mathrm{kcal} \mathrm{mol}^{-1}$ below $\mathbf{5}(\mathbf{t})$, as reported in Table S1. In fact, besides aurophilicity, the secondary interactions of the bulky ligands must be taken into account (see Figure S3 and comments in the Supporting information for details). The unexpected stability of $\mathbf{5 ( f s )}$ compared to $\mathbf{5}(\mathbf{t})$ is likely due to the pronounced shift of the Au biscarbene moieties and the onset of two Au- $\pi$ interactions with both phenyl rings (the distance between the metal and the 
centroids is $3.7 \AA$ ), which are arranged so that the overall molecular symmetry is almost perfectly $\mathrm{C}_{2}$ (binary axis orthogonal to the $\mathrm{Au}-\mathrm{Au}$ axis).

Focusing on complexes $\mathbf{5}(\mathbf{f} s)$ and $\mathbf{6}(\mathbf{t})$, the presence of symmetry in the former reflects in a greater stability in terms of HOMO-LUMO gap (Table 2). The frontier Kohn-Sham MOs in 6(t) have strong metal (HOMO) and strong ligand character, respectively; conversely, in 5(fs), HOMO lobes are significantly expanded on the ligands (51.01\% Au nuclei and $28.28 \%$ ligands), while LUMO is strongly ligand centered (Figure 6).

Table 2. HOMO-LUMO gaps (eV), HOMO and LUMO composition (percentage contributions of $\mathrm{Au}$ and ligands) of complexes $\mathbf{5}(\mathbf{f s})$ and $\mathbf{6}(\mathbf{t})$; level of theory: ZORA-BLYP-D3(BJ)/TZ2P. A complete analysis for all the conformers is reported in Table S4.

\begin{tabular}{|l|l|l|l|l|l|}
\hline \multirow{2}{*}{\begin{tabular}{l} 
LUMO- \\
\cline { 3 - 6 }
\end{tabular}} & \multicolumn{2}{|l|}{ HOMO } & LUMO \\
\cline { 3 - 6 } & $\mathrm{Au}$ & Ligands & Au & Ligands \\
\hline $\mathbf{5 ( f s )}$ & 3.032 & 51.01 & 28.28 & 5.74 & 78.6 \\
\hline $\mathbf{6 ( t )}$ & 2.891 & 72.14 & - & - & 87.46 \\
\hline
\end{tabular}

${ }^{a}$ Only the relevant contributions are summed, explaining why the total sum is not $100 \%$.
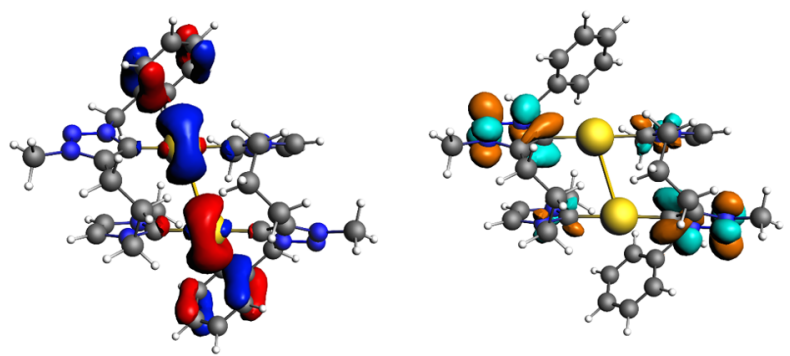

$\mathbf{5 ( f s )}$
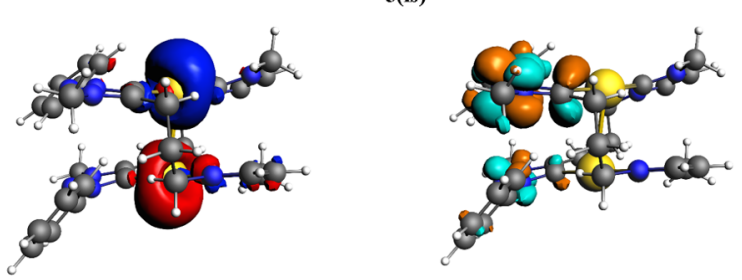
Figure 6. Kohn-Sham HOMOs (left) and LUMOs (right) of complexes 5(fs) and $\mathbf{6}(\mathbf{t})$. Level of theory: ZORA-BLYP-D3(BJ)/TZ2P; orbital isosurfaces: 0.03 .

In order to understand the luminescence properties of $\mathbf{6}(\mathbf{t})$ and $\mathbf{5}(\mathbf{f} s)$, we first calculated their absorption spectra in gas phase, with the aim of identifying the lowest and strongest excitations from the ground state. The SAOP model combined with all electron TZ2P basis sets was employed and scalar relativistic effects were taken into account.

For $\mathbf{6}(\mathbf{t})$, the lowest singlet-singlet absorption $\left(\mathrm{S}_{1} \leftarrow \mathrm{S}_{0}\right)$ falls in the near visible region at $390.6 \mathrm{~nm}$ ( $\mathrm{f}=0.09)$ and corresponds to an almost purely monoelectronic HOMO-LUMO transition (98.3\%) with net metal-to-ligand-charge-transfer (MLCT) character. A bunch of absorptions at close wavelengths is then found in the range $375-346 \mathrm{~nm}$. In these transitions, the MLCT character is less pronounced, because the filled MOs of the couples involved in the dominant excitations have a significant ligand percentage contribution. Another group of close peaks falls in the range 346-328 $\mathrm{nm}$ with similar or even pure ligand-to-ligand character. A strong absorption at $310 \mathrm{~nm}$ is due to ligand-based transitions, but the lack of dominant contributions precludes a precise assignment.

The lowest absorption in the UV-vis spectrum of $\mathbf{5 ( f s )}$ is blue-shifted if compared to that of $\mathbf{6}(\mathbf{t})$; it is computed at $378 \mathrm{~nm}(\mathrm{f}=0.002)$. It is ascribed to an almost pure HOMO-LUMO monoelectronic transition (99.4\%) with net MLCT character as observed for $\mathbf{6}(\mathbf{t})$. Another absorption of similar intensity $(\mathrm{f}=0.004)$ is computed at $365 \mathrm{~nm}$ and has monoelectronic composition HOMO-1 LUMO+1 $(99.4 \%)$ with ligand to ligand character. In the transitions corresponding to the intense peaks computed at 337, 322 and $315 \mathrm{~nm}$ the MLCT character decreases, since the contributions of the Au lobes on the involved filled MOs is rather small. Finally, the very intense absorptions at 289 $\mathrm{nm}$ and $283 \mathrm{~nm}(\mathrm{f}=0.07$ in both cases $)$ involve couples of delocalized MOs with significant metal and ligand contributions. 
The composition of the lowest singlet-triplet absorption $\left(T_{1} \leftarrow S_{0}\right)$ is almost identical to the singletsinglet one, i.e. 99\% HOMO-LUMO, and falls at $384 \mathrm{~nm}(\mathbf{5}(\mathbf{f s}))$ and at $397.3 \mathrm{~nm}(\mathbf{6}(\mathbf{t}))$. Both $\mathbf{5 ( f s )}$ and $\mathbf{6}(\mathbf{t})$ were fully optimized in the lowest triplet state and the phosphorescence wavelengths were estimated subtracting the energy of the ground state (level of theory: ZORA-BLYP/TZ2P sc). Emission as phosphorescence is calculated at $384 \mathrm{~nm}(\mathbf{5}(\mathbf{f s}))$ and $431 \mathrm{~nm}(\mathbf{6}(\mathbf{t}))$. These wavelengths are blu-shifted with respect to the experimental ones, but their separation is in very good agreement (experimental $47 \mathrm{~nm}$ vs. calculated $50 \mathrm{~nm}$ ), considering also that SAOP potential, which is optimized for excited states, was not used because not available for the triplet geometry optimization.

The $\mathrm{Au} \cdots \mathrm{Au}$ interaction is greatly enhanced in the $\mathrm{T}_{1}$ excited state, with much shorter $\mathrm{Au} \cdots \mathrm{Au}$ distances compared those measured in the ground state (see Table S3). This was already observed in other dinuclear gold(I) complexes having bridging dicarbenes or diphosphines coordinated to the metal centers..$^{283742}$

Synthesis of palladium(II) complex. The study on the coordinating properties of this type of $n$ NHC- $t z$ NHC ligands was also extended to palladium(II), a metal center characterized by a coordination geometry different from linearity, with the aim to explore the possibility of obtaining isomers even when this type of ligands are in a chelate fashion. The transmetalation of the dicarbene ligand was successfully used for the syntheses of palladium(II) complexes $\mathbf{8 / 8}$ ' starting from the silver(I) complex 4. $\left[\mathrm{PdCl}_{2}(\mathrm{COD})\right](\mathrm{COD}=1,5$-cyclooctadiene) was used as palladium precursor due to the labile nature of the diene ligand and the reaction was performed in acetonitrile at room temperature for 3 hours with an $\mathrm{Ag}: \mathrm{Pd} 2: 1$ molar ratio (Scheme 5). 


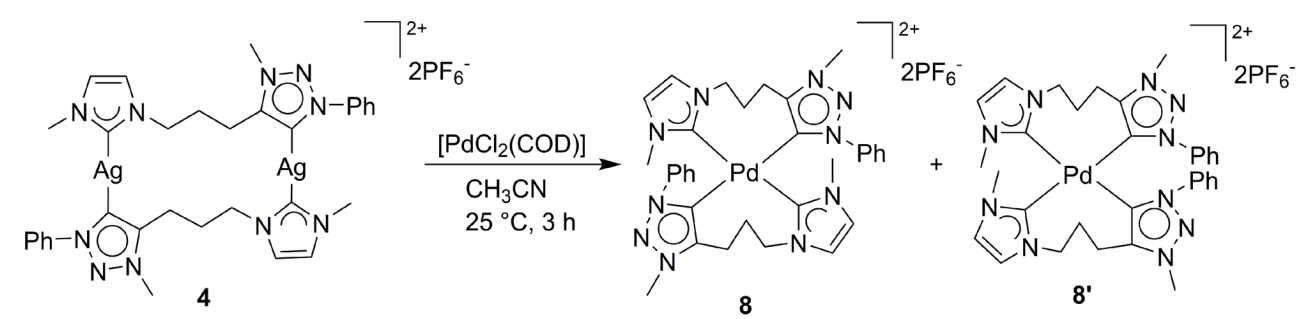

Scheme 5. Synthesis of the complexes $\mathbf{8 / 8}$,

As already observed for gold complexes, two sets of signals can be detected in both the ${ }^{\mathrm{H}}$ and ${ }^{13} \mathrm{C}$ NMR spectra, associable to the two isomers $\mathbf{8}$ and $\mathbf{8}^{\prime}$ (Scheme 5) in a 3:2 ratio (referred to the $\mathrm{CH}_{3}$ signals). This might be explained with a different stability of the two species, related to the different steric hindrance around the metal center. In fact, in complex $\mathbf{8}$, the phenyl rings are in close proximity and therefore this conformer is expected to be less stable.

The chelating coordination of the ligands on the metal center is supported by the presence of several multiplets associated to the $\mathrm{CH}_{2}$ protons of the bridge, as a consequence of the formation of a rigid 8-membered metallacycle. The ${ }^{13} \mathrm{C}$ NMR spectrum further supports the coordination of the dicarbene ligand to the palladium(II) center: the $n \mathrm{NHC}$ carbene carbon signal is observed at $\delta$ ca. $171 \mathrm{ppm}$, coherent with the literature. ${ }^{33-45}$ The ESI-MS spectra accredit the coordination of two ligands on the same metal center due to the presence of the fragment $\left[\mathrm{PdL}_{2} \mathrm{PF}_{6}\right]^{+}$(with $\mathrm{L}=n \mathrm{NHC}$ $t z$ NHC dicarbene ligand) at $m / z, 813.19$.

By slow diffusion of diethyl ether into an acetonitrile solution of complexes $\mathbf{8 / 8}$, single crystals were obtained; the crystal structure was solved by X-ray diffraction studies. In Figure 7, the molecular structure of the palladium complex $\mathbf{8}$ is shown. 


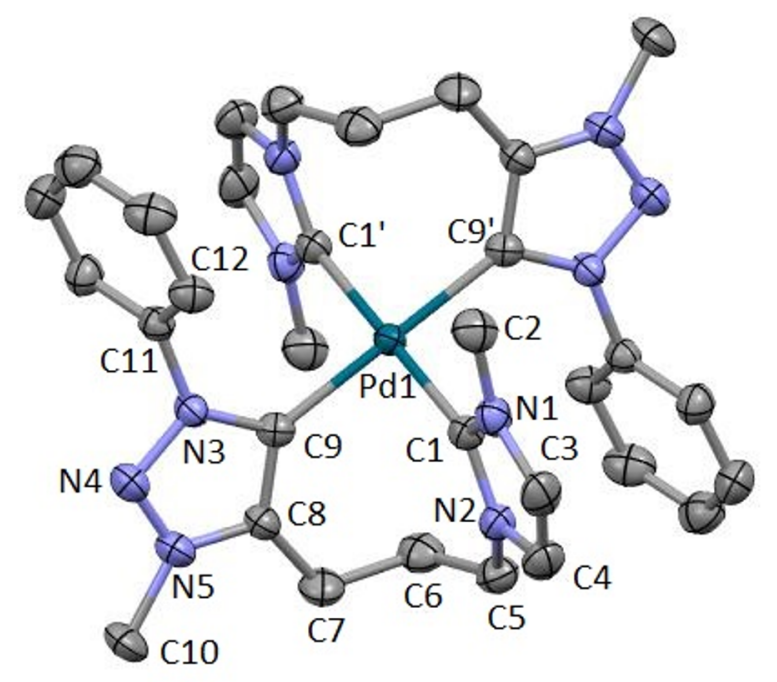

Figure 7. ORTEP-style view of cationic compound $\mathbf{8}$, with atomic numbering scheme; ellipsoids are drawn at their $30 \%$ probability level. Hydrogen atoms have been omitted for clarity. Selected bond distances $(\AA)$ and angles $\left({ }^{\circ}\right)$ : Pd1-C9 2.058(5), Pd1-C1 2.062(6), N1-C1 1.354(7), N2-C1 1.364(7), N3-N4 1.337(6), N4-N5 1.311(7); C9'-Pd1-C1 92.4(2), C9-Pd1-C1 87.6(2). Code for atoms: ‘ = -x, $-\mathrm{y},-\mathrm{z}$.

It confirms the dicationic nature of complex $\mathbf{8}$ with two dicarbene ligands chelating on the palladium center and forming two 8-membered rings. The cationic compound crystallizes with $\mathrm{PF}_{6}$ anion and acetonitrile solvent molecules. The structure of the cationic complex is centrosymmetric, with the metal atom located on the inversion center. The palladium(II) presents, as expected, a square planar configuration: the C1-Pd1-C9 and C9-Pd1-C1 deviated slightly from the ideal $90^{\circ}$ value $\left(92.4(2)\right.$ and $\left.87.6(2)^{\circ}\right)$. The distances between the palladium(II) center and the carbene carbon atoms are 2.062(6) $\AA(n \mathrm{NHC})$ and 2.058(5) $\AA(t z \mathrm{NHC})$, in the expected range of distances for this type of compounds..$^{2664648}$ The dihedral angle between the phenyl substituent and the triazole ring is twisted by $71.84^{\circ}$, thus minimizing the steric hindrance. 


\section{CONCLUSIONS}

Gold(I) and palladium(II) complexes based on bidentate heteroditopic $n$ NHC- $t z$ NHC dicarbene ligands were successfully synthesized via transmetalation of the dicarbene ligand from the corresponding silver(I) complex. The gold(I) complexes are dinuclear species with the two bidentate ligands bridging the two metal centers, while the palladium(II) complex is mononuclear with the two dicarbene ligands chelating the metal. In the case of gold(I) and palladium(II) complexes, two isomers, i.e. head-to-tail or head-to-head, were obtained, due to the two different carbene moieties on the ligand. The stability of the other plausible gold(I) isomers was analyzed through DFT calculations, which confirm that the species that crystallize are the most stable ones. The presence of the two isomers was not evident for silver(I) complexes, probably because of the well-known dynamic behavior of the silver carbene species. ${ }^{34}$ Interestingly, the gold(I) complexes were found to emit (PLQY 8\%) in the blue region; the comparison between the measured luminescence and the results of the DFT calculations for the $S_{0} \leftarrow T_{1}$ transition are in very nice agreement.

Considering the presence of two different carbene functions on the ligand, we are currently working on the possibility of obtaining heterobimetallic complexes via step-by-step deprotonation of the azolium rings of the dicarbene proligand.

\section{EXPERIMENTAL SECTION}

Materials and methods. Reagents and solvents were high-purity commercially available products and generally used as received. All manipulations were carried out using standard Schlenk techniques under an atmosphere of argon or dinitrogen. NMR spectra were recorded on a Bruker Avance $300 \mathrm{MHz}$ (300.1 MHz for ${ }^{1} \mathrm{H}, 121.5$ for ${ }^{31} \mathrm{P}$ and 75.5 for ${ }^{13} \mathrm{C}$ ) or on a Bruker DMX 600 (599.98 $\mathrm{MHz}$ for ${ }^{\mathrm{H}} \mathrm{H}$ and $150.07 \mathrm{MHz}$ for ${ }^{13} \mathrm{C}$ ) or on a Bruker DRX $400\left(400.13 \mathrm{MHz}\right.$ for ${ }^{\mathrm{H}}$ and 100.62 $\mathrm{MHz}$ for ${ }^{13} \mathrm{C}$ ); chemical shifts $(\delta)$ are reported in units of ppm relative to the residual solvent 
signals. High-resolution mass spectroscopy (HRMS) analyses were performed in the ESI mode using a microTOF instrument (Bruker Daltonics). ESI-MS analyses were performed using a LCQDuo (Thermo-Finnigan) operating in positive ion mode. Compounds were dissolved in acetonitrile and the sample solutions were directly infused into the ESI source by a syringe pump. Elemental analyses were carried out with a Thermo Scientific FLASH 2000 apparatus. 1-(pent-4-ynyl)-1Himidazole, proligand 1-I was prepared according to literature procedure ${ }^{31}$ In few cases the elemental analysis results exceed the range accepted for establishing the analytical purity of a compound, but they represent the best obtained values. The purity of the compounds was also established on the basis of NMR spectra (the products are completely soluble in the NMR solvent and only the signals of the analyzed species are recorded) and HR-ESI measurements.

\section{Synthesis of the imidazolium-triazolium salts}

Synthesis of 4-[3-(1H-imidazol-1-yl)propyl]-1-phenyl-1H-1,2,3-triazole. 1-(pent-4-ynyl)-1Himidazole $(0.30 \mathrm{~g}, 2.25 \mathrm{mmol})$, sodium-L-ascorbate $(0.24 \mathrm{~g}, 1.18 \mathrm{mmol})$ and copper(II) sulfate pentahydrate $(0.29 \mathrm{~g}, 1.16 \mathrm{mmol})$ were placed in a two-neck round bottom flask. Methanol $(10 \mathrm{~mL})$ and a solution of phenyl azide $(0.5 \mathrm{M}$ in t-butyl-methylether, $4.5 \mathrm{~mL}, 2.25 \mathrm{mmol})$ were then added and the reaction mixture was left under stirring for 72 hours at $25^{\circ} \mathrm{C}$. Afterwards, methanol was removed under vacuum; the residue was dissolved in $\mathrm{CH}_{2} \mathrm{Cl}_{2}(50 \mathrm{~mL})$ and washed with water $(3 \times$ $50 \mathrm{~mL}$ ). The organic phase was dried over $\mathrm{Na}_{2} \mathrm{SO}_{4}$ and the solvent was then removed, affording a yellow oil, that was further washed with diethyl ether $(3 \times 5 \mathrm{~mL})($ yield $33 \%)$. ${ }^{\mathrm{H}} \mathrm{NMR}\left(\mathrm{CDCl}_{3}, 300\right.$ $\mathrm{MHz}) \delta=2.30\left(\mathrm{~s}\right.$ br, $\left.2 \mathrm{H}, \mathrm{CH}_{2}\right), 2.65\left(\mathrm{~s}\right.$ br, $\left.2 \mathrm{H}, \mathrm{CH}_{2}\right), 4.10\left(\mathrm{~s} \mathrm{br}, 2 \mathrm{H}, \mathrm{CH}_{2}\right), 7.26-7.42(\mathrm{~m}, 9 \mathrm{H}, \mathrm{CH}+$ $\mathrm{CH} \mathrm{Ar}+\mathrm{CH}$ tz $+\mathrm{CH}$ im)

Synthesis of 3-(phenyl)-1-methyl-5-[3-(3-methyl-1H-imidazol-3-ium-1-yl)propyl]-3H-1,2,3triazol-1-ium diiodide 2-I. $\mathrm{CH}_{3} \mathrm{I}(0.30 \mathrm{~mL}, 4.80 \mathrm{mmol})$ was added to a solution of 4 -[3-(1Himidazol-1-yl)propyl]-1-(phenyl)-1H-1,2,3-triazole $(0.11 \mathrm{~g}, 0.45 \mathrm{mmol})$ in $\mathrm{CH}_{3} \mathrm{CN}$ (5 mL). The reaction mixture was refluxed for 18 hours, obtaining an orange solution. The solvent was removed under vacuum and the orange oil was washed with diethyl ether, giving an orange solid (yield 82\%). 
${ }^{\prime} \mathrm{H}$ NMR $\left(\mathrm{CD}_{3} \mathrm{CN}, 300 \mathrm{MHz}\right) \delta=2.50\left(\mathrm{t},{ }^{3} \mathrm{~J}_{\text {нн }}=7.5 \mathrm{~Hz}, 2 \mathrm{H}, \mathrm{CH}_{2}\right), 3.13\left(\mathrm{t},{ }^{3} \mathrm{~J}_{\text {нн }}=7.5 \mathrm{~Hz}, 2 \mathrm{H}, \mathrm{CH}_{2}\right)$, $3.89\left(\mathrm{~s}, 3 \mathrm{H}, \mathrm{CH}_{3}\right), 4.44\left(\mathrm{~s}, 3 \mathrm{H}, \mathrm{CH}_{3}\right), 4.48\left(\mathrm{t},{ }^{3} \mathrm{~J}_{\text {нн }}=7.5 \mathrm{~Hz}, 2 \mathrm{H}, \mathrm{CH}_{2}\right), 7.45(\mathrm{~s}, 1 \mathrm{H}, \mathrm{CH}), 7.69(\mathrm{~m}, 3 \mathrm{H}$, $\mathrm{CH}$ Ar), $7.76(\mathrm{~s}, 1 \mathrm{H}, \mathrm{CH}), 7.99(\mathrm{~m}, 2 \mathrm{H}, \mathrm{CH} \mathrm{Ar}), 9.24\left(\mathrm{CH}\right.$ tz), $9.44\left(\mathrm{CH}\right.$ im) ${ }^{.3} \mathrm{C}\left\{{ }^{\prime} \mathrm{H}\right\} \mathrm{NMR}\left(\mathrm{CD}_{3} \mathrm{CN}\right.$, $75 \mathrm{MHz}): \delta=14.9\left(\mathrm{CH}_{2}\right), 20.4\left(\mathrm{CH}_{2}\right), 36.4\left(\mathrm{CH}_{3}\right), 39.0\left(\mathrm{CH}_{3}\right), 48.3\left(\mathrm{CH}_{2}\right), 122.3(\mathrm{CH}), 123.9(\mathrm{CH})$, 128.2 (CH tz), 129.2 (CH Ar), 129.3 (CH Ar), 129.7 (CH Ar), 132.1 (C Ar), 136.3 (CH im), 144.0 (C).

\section{General synthesis of 3-(substituted)-1-methyl-5-[3-(3-methyl-1H-imidazol-3-ium-1-} yl)propyl]-3H-1,2,3-triazol-1-ium bis(hexafluorophosphate) 1-PF and 2-PF$_{6}$. A solution of $\mathrm{KPF}_{6}$ (1.96 mmol) in $\mathrm{H}_{2} \mathrm{O}(3 \mathrm{~mL})$ was added to a solution of 1-I or 2-I $(0.37 \mathrm{mmol})$ in $\mathrm{MeOH}(3 \mathrm{~mL})$. The mixture was stirred for 24 hours at room temperature, affording a light brown solid that was filtered and dried under vacuum. 1-PF . Yield 99\%. ${ }^{2} \mathrm{H}$ NMR $\left(\mathrm{CD}_{3} \mathrm{CN}, 300 \mathrm{MHz}\right) \delta=2.14\left(\mathrm{t},{ }^{3} \mathbf{J}_{\text {нн }}=7.5 \mathrm{~Hz}\right.$, $\left.2 \mathrm{H}, \mathrm{CH}_{2}\right), 2.78\left(\mathrm{t},{ }^{3} \mathrm{~J}_{\mathrm{нн}}=7.5 \mathrm{~Hz}, 2 \mathrm{H}, \mathrm{CH}_{2}\right), 3.83\left(\mathrm{~s}, 3 \mathrm{H}, \mathrm{CH}_{3}\right), 4.09\left(\mathrm{~s}, 3 \mathrm{H}, \mathrm{CH}_{3}\right), 4.20\left(\mathrm{t},{ }^{3} \mathrm{~J}_{\mathrm{Hн}}=7.5 \mathrm{~Hz}\right.$, $\left.2 \mathrm{H}, \mathrm{CH}_{2}\right), 5.68\left(\mathrm{~s}, 2 \mathrm{H}, \mathrm{CH}_{2}\right), 7.36(\mathrm{~s}, 1 \mathrm{H}, \mathrm{CH}), 7.39(\mathrm{~s}, 1 \mathrm{H}, \mathrm{CH}), 7.46(\mathrm{~s}, 5 \mathrm{H}, \mathrm{CH} \mathrm{Ar}), 8.19(\mathrm{~s}, 1 \mathrm{H}$, $\mathrm{CH}$ tz), $8.45(\mathrm{~s}, 1 \mathrm{H}, \mathrm{CH} \mathrm{im}) .{ }^{\mathrm{i}} \mathrm{C}\left\{{ }^{\mathrm{H}} \mathrm{H}\right\} \mathrm{NMR}\left(\mathrm{CD}_{3} \mathrm{CN}, 75 \mathrm{MHz}\right): \delta=20.8\left(\mathrm{CH}_{2}\right), 27.9\left(\mathrm{CH}_{2}\right), 37.0$ $\left(\mathrm{CH}_{3}\right), 38.7\left(\mathrm{CH}_{3}\right), 49.1\left(\mathrm{CH}_{2}\right), 57.9\left(\mathrm{CH}_{2}\right), 123.3(\mathrm{CH}), 124.8(\mathrm{CH}), 129.2(\mathrm{CH}$ tz), $130.1(\mathrm{CH} \mathrm{Ar})$, 130.2 (CH Ar), 130.6 (CH Ar), 133.1 (C Ar), $137.3\left(\mathrm{CH}\right.$ im), $144.3(\mathrm{C}) .{ }^{3} \mathrm{P}\left\{{ }^{1} \mathrm{H}\right\} \mathrm{NMR}\left(\mathrm{CD}_{3} \mathrm{CN}, 121\right.$ $\mathrm{MHz}): \delta=-144.6$ (heptet, $\left.\mathrm{PF}_{6}\right) . \mathbf{2}-\mathrm{PF}_{6}$. Off-white solid, yield 81\%. 'H NMR $\left(\mathrm{CD}_{3} \mathrm{CN}, 300 \mathrm{MHz}\right) \delta=$ $2.32\left(\mathrm{t},{ }^{3} \mathrm{~J}_{\text {нН }}=7.5 \mathrm{~Hz}, 2 \mathrm{H}, \mathrm{CH}_{2}\right), 2.93\left(\mathrm{t},{ }^{3} \mathrm{~J}_{\text {нн }}=7.5 \mathrm{~Hz}, 2 \mathrm{H}, \mathrm{CH}_{2}\right), 3.86\left(\mathrm{~s}, 3 \mathrm{H}, \mathrm{CH}_{3}\right), 4.24\left(\mathrm{~s}, 3 \mathrm{H}, \mathrm{CH}_{3}\right)$, $4.29\left(\mathrm{t},{ }^{3} \mathrm{~J}_{\text {нн }}=7.5 \mathrm{~Hz}, 2 \mathrm{H}, \mathrm{CH}_{2}\right), 7.39(\mathrm{~s} \mathrm{br}, 1 \mathrm{H}, \mathrm{CH}), 7.46(\mathrm{~s} \mathrm{br}, 1 \mathrm{H}, \mathrm{CH}), 7.72(\mathrm{~m}, 3 \mathrm{H}, \mathrm{CH} \mathrm{Ar}), 7.86$ (m, 2H, CH Ar), $8.55\left(\mathrm{~s}, 1 \mathrm{H}, \mathrm{CH}\right.$ tz), $8.74\left(\mathrm{~s}, 1 \mathrm{H}, \mathrm{CH}\right.$ im). ${ }^{13} \mathrm{C}\left\{{ }^{\prime} \mathrm{H}\right\} \mathrm{NMR}\left(\mathrm{CD}_{3} \mathrm{CN}, 75 \mathrm{MHz}\right): \delta=$ $20.8\left(\mathrm{CH}_{2}\right), 27.8\left(\mathrm{CH}_{2}\right), 37.0\left(\mathrm{CH}_{3}\right), 39.0\left(\mathrm{CH}_{3}\right), 49.1\left(\mathrm{CH}_{2}\right), 122.5(\mathrm{CH}), 123.3(\mathrm{CH}), 125.0(\mathrm{CH}$ tz), 127.7 (CH Ar), 131.5 (CH Ar), $133.0(\mathrm{CH} \mathrm{Ar}), 136.0$ (C Ar), $137.2\left(\mathrm{CH}\right.$ im), $144.8(\mathrm{C}) .{ }^{3} \mathrm{P}\left\{{ }^{\prime} \mathrm{H}\right\}$ $\operatorname{NMR}\left(\mathrm{CD}_{3} \mathrm{CN}, 121 \mathrm{MHz}\right): \delta=-144.7$ (heptet, $\left.\mathrm{PF}_{6}\right)$.

\section{Synthesis of the silver(I) complexes 3 and 4}

Synthesis of 3. The proligand 1-PF $6.10 \mathrm{~g}, 0.17 \mathrm{mmol})$ and $\mathrm{Ag}_{2} \mathrm{O}(0.20 \mathrm{~g}, 0.87 \mathrm{mmol})$ were placed in a two-neck round bottom flask. Subsequently, $\mathrm{CH}_{3} \mathrm{CN}(15 \mathrm{~mL})$ was added and the reaction 
mixture was left under stirring for 48 hours at $85^{\circ} \mathrm{C}$. Afterwards, it was filtered on Celite and the solvent was removed under vacuum, giving 3 as a light brown oil. ${ }^{\mathrm{H}} \mathrm{NMR}\left(\mathrm{CD}_{3} \mathrm{CN}, 300 \mathrm{MHz}\right) \delta=$ $2.39\left(\mathrm{t},{ }^{3} \mathrm{~J}_{\text {нН }}=6.6 \mathrm{~Hz}, 2 \mathrm{H}, \mathrm{CH}_{2}\right), 2.77\left(\mathrm{t},{ }^{3} \mathrm{~J}_{\text {нн }}=6.6 \mathrm{~Hz}, 2 \mathrm{H}, \mathrm{CH}_{2}\right), 3.51\left(\mathrm{~s}, 3 \mathrm{H}, \mathrm{CH}_{3}\right), 4.07\left(\mathrm{~s}, 3 \mathrm{H}, \mathrm{CH}_{3}\right)$, $4.11\left(\mathrm{~m}, 2 \mathrm{H}, \mathrm{CH}_{2}\right), 5.40\left(\mathrm{~s}, 2 \mathrm{H}, \mathrm{CH}_{2}\right), 7.25(\mathrm{~m}, 6 \mathrm{H}, \mathrm{CH}+\mathrm{CH} \mathrm{Ar}), 7.45(\mathrm{~s}, 1 \mathrm{H}, \mathrm{CH}) .{ }^{\mathrm{i}} \mathrm{C}\left\{{ }^{\prime} \mathrm{H}\right\} \mathrm{NMR}$ $\left(\mathrm{CD}_{3} \mathrm{CN}, 75 \mathrm{MHz}\right): \delta=22.1\left(\mathrm{CH}_{2}\right), 29.2\left(\mathrm{CH}_{2}\right), 37.1\left(\mathrm{CH}_{3}\right), 38.8\left(\mathrm{CH}_{3}\right), 50.5\left(\mathrm{CH}_{2}\right), 59.6\left(\mathrm{CH}_{2}\right), 121.8$ (CH), $124.2(\mathrm{CH}), 128.9$ (CH Ar), 129.6 (CH Ar), 129.8 (CH Ar), 136.0 (C Ar), 148.5 (C), 164.2 (CAg $t z \mathrm{NHC}$ ), 181.1 (CAg $n \mathrm{NHC}$ ). Traces of acetic acid are present (as indicated by the signals at ca. 20 and $173 \mathrm{ppm}$ ) probably due to the hydrolysis of the acetonitrile solvent. HR-MS (positiveions, $\left.\mathrm{CD}_{3} \mathrm{CN}\right): \mathrm{m} / \mathrm{z}$ calcd for $\mathrm{C}_{17} \mathrm{H}_{21} \mathrm{AgN}_{5}\left(25 \%,[\mathrm{AgL}]^{+}\right)$402.0842, found 402.0958, $\mathrm{m} / \mathrm{z}$ calcd for $\mathrm{C}_{34} \mathrm{H}_{42} \mathrm{Ag}_{2} \mathrm{~F}_{6} \mathrm{~N}_{10} \mathrm{P}\left(100 \%,\left[\mathrm{Ag}_{2} \mathrm{~L}_{2} \mathrm{PF}_{6}\right]^{+}\right)$951.1331, found 951.1356; with $\mathrm{L}=n \mathrm{NHC}-t z \mathrm{NHC}$ dicarbene ligand.

Synthesis of 4. Proligand 2-PF 6 (0.051 g, $0.09 \mathrm{mmol})$ and $\mathrm{Ag}_{2} \mathrm{O}(0.12 \mathrm{~g}, 0.50 \mathrm{mmol})$ were placed in a two-neck round bottom flask. Acetonitrile $(7 \mathrm{~mL})$ was added and the reaction mixture was left under stirring for 48 hours at $85{ }^{\circ} \mathrm{C}$. Afterwards, it was filtered on Celite and the volatiles were removed at low pressure. An off-white solid formed upon addition of diethyl ether $(20 \mathrm{~mL})$ and it was filtered and dried under vacuum (yield $78 \%)$. ${ }^{1} \mathrm{H}$ NMR $\left(\mathrm{CD}_{3} \mathrm{CN}, 300 \mathrm{MHz}\right) \delta=2.36(\mathrm{~m}, 2 \mathrm{H}$, $\left.\mathrm{CH}_{2}\right), 2.81\left(\mathrm{~m}, 2 \mathrm{H}, \mathrm{CH}_{2}\right), 3.50\left(\mathrm{~s}, 3 \mathrm{H}, \mathrm{CH}_{3}\right), 4.07\left(\mathrm{t},{ }^{3} \mathrm{~J}_{\text {нн }}=6.6 \mathrm{~Hz}, 2 \mathrm{H}, \mathrm{CH}_{2}\right), 4.15\left(\mathrm{~s}, 3 \mathrm{H}, \mathrm{CH}_{3}\right), 7.09$ (s, 1H, CH), $7.20(\mathrm{~s}, 1 \mathrm{H}, \mathrm{CH}), 7.48(\mathrm{~m}, 3 \mathrm{H}, \mathrm{CH} \mathrm{Ar}), 7.73(\mathrm{~m}, 2 \mathrm{H}, \mathrm{CH} \mathrm{Ar}) .{ }^{18} \mathrm{C}\left\{{ }^{\mathrm{H}} \mathrm{H}\right\} \mathrm{NMR}\left(\mathrm{CD}_{3} \mathrm{CN}\right.$, $75 \mathrm{MHz}): \delta=21.8\left(\mathrm{CH}_{2}\right), 28.3\left(\mathrm{CH}_{2}\right), 37.5\left(\mathrm{CH}_{3}\right), 38.7\left(\mathrm{CH}_{3}\right), 50.0\left(\mathrm{CH}_{2}\right), 121.3(\mathrm{CH}), 123.8(\mathrm{CH})$, 124.6 (CH Ar), 130.6 (CH Ar), 131.3 (CH Ar), 140.7 (C Ar), 148.2 (C), 164.5 (CAg tzNHC), 181.5 (CAg $n \mathrm{NHC}$ ). HR-MS (positive-ions, $\left.\mathrm{CD}_{3} \mathrm{CN}\right): \mathrm{m} / z$ calcd for $\left.\mathrm{C}_{32} \mathrm{H}_{38} \mathrm{Ag}_{2} \mathrm{~F}_{6} \mathrm{~N}_{10} \mathrm{P}\left(100 \%, \mathrm{Ag}_{2} \mathrm{~L}_{2} \mathrm{PF}_{6}\right]^{+}\right)$ 923.1021, found 923.1026, with L = nNHC- $t z$ NHC dicarbene ligand.

\section{Synthesis of the gold(I) complexes 5/5' and 6/6'.}

Synthesis of 5/5'. Method A. Proligand 1-PF $(0.049 \mathrm{~g}, 0.086 \mathrm{mmol})$ and $\mathrm{Ag}_{2} \mathrm{O}(0.10 \mathrm{~g}, 0.44$ mmol) were placed in a two-neck round bottom flask. Acetonitrile $(10 \mathrm{~mL})$ was added and the reaction mixture was left under stirring for 48 hours at $85^{\circ} \mathrm{C}$. Afterwards, the mixture was filtered 
on Celite and a solution of $\mathrm{AuCl}\left(\mathrm{SMe}_{2}\right)(0.026 \mathrm{~g}, 0.088 \mathrm{mmol})$ in acetonitrile $(5 \mathrm{~mL})$ was added to the filtrate. The reaction mixture was left under stirring for 3 hours at room temperature and then filtered on Celite; finally, the solvent was removed under vacuum in order to obtain an oil. Recrystallization by $\mathrm{CH}_{3} \mathrm{CN} / \mathrm{Et}_{2} \mathrm{O}$ affords the product as an off-white solid (global yield 78\%). Anal. Calcd for $\mathrm{C}_{34} \mathrm{H}_{42} \mathrm{~N}_{10} \mathrm{Au}_{2} \mathrm{P}_{2} \mathrm{~F}_{12}$ : C, 32.02; H, 3.32; N, 10.99\%. Found: C, 31.18; H, 3.25; N, 10.72\%. ESIMS (positive-ions, $\mathrm{CH}_{3} \mathrm{CN}$ ): $\mathrm{m} / z$ 1129.27 $\left[100 \%, \mathrm{Au}_{2} \mathrm{~L}_{2} \mathrm{PF}_{6}\right]^{+}$; with $\mathrm{L}=n \mathrm{NHC}-t z \mathrm{NHC}$ dicarbene ligand. The 'H-NMR spectra show two set of signals, attributable to the complexes $\mathbf{5}$ and $\mathbf{5}$ ', in a 1:1 ratio. 5.' $\mathrm{H} \mathrm{NMR}\left(\mathrm{CD}_{3} \mathrm{CN}, 600 \mathrm{MHz}\right.$ ) $\delta=2.53\left(\mathrm{~m}, 2 \mathrm{H}, \mathrm{CH}_{2}\right), 2.86\left(\mathrm{~m}, 2 \mathrm{H}, \mathrm{CH}_{2}\right), 3.42\left(\mathrm{~s}, 3 \mathrm{H}, \mathrm{CH}_{3}\right)$, $4.10\left(\mathrm{~s}, 3 \mathrm{H}, \mathrm{CH}_{3}\right), 4.23\left(\mathrm{~m}, 2 \mathrm{H}, \mathrm{CH}_{2}\right), 5.44\left(\mathrm{~s}, 2 \mathrm{H}, \mathrm{CH}_{2}\right), 7.13(\mathrm{~d}, 1 \mathrm{H}, \mathrm{CH}), 7.25(\mathrm{~d}, 1 \mathrm{H}, \mathrm{CH}), 7.33$ (m, 5H, CH Ar). ${ }^{13} \mathrm{C}\left\{{ }^{\prime} \mathrm{H}\right\} \mathrm{NMR}\left(\mathrm{CD}_{3} \mathrm{CN}, 150 \mathrm{MHz}\right): \delta=22.0\left(\mathrm{CH}_{2}\right), 28.0\left(\mathrm{CH}_{2}\right), 37.7\left(\mathrm{CH}_{3}\right), 38.0$ $\left(\mathrm{CH}_{3}\right), 49.9\left(\mathrm{CH}_{2}\right), 59.1\left(\mathrm{CH}_{2}\right), 121.2(\mathrm{CH}), 124.4(\mathrm{CH}), 128.6(\mathrm{CH} \mathrm{Ar}), 129.0(\mathrm{CH}$ Ar $), 129.7(\mathrm{CH}$ Ar), 135.5 (C Ar), 147.8 (C), 170.1 (CAu $t z N H C), 185.9$ (CAu $n$ NHC). 5'. 'H NMR (CD $\mathrm{CN}_{3}, 600$ $\mathrm{MHz},) \delta=2.52\left(\mathrm{~m}, 2 \mathrm{H}, \mathrm{CH}_{2}\right), 2.87\left(\mathrm{~m}, 2 \mathrm{H}, \mathrm{CH}_{2}\right), 3.62\left(\mathrm{~s}, 3 \mathrm{H}, \mathrm{CH}_{3}\right), 4.06\left(\mathrm{~s}, 3 \mathrm{H}, \mathrm{CH}_{3}\right), 4.26(\mathrm{~m}, 2 \mathrm{H}$, $\left.\mathrm{CH}_{2}\right), 5.33\left(\mathrm{~s}, 2 \mathrm{H}, \mathrm{CH}_{2}\right), 7.17(\mathrm{~d}, 1 \mathrm{H}, \mathrm{CH}), 7.20(\mathrm{~d}, 1 \mathrm{H}, \mathrm{CH}), 7.28-7.38(\mathrm{~m}, 5 \mathrm{H}, \mathrm{CH} \mathrm{Ar}) .{ }^{\mathrm{r}} \mathrm{C}\left\{{ }^{\prime} \mathrm{H}\right\}$ NMR $\left(\mathrm{CD}_{3} \mathrm{CN}, 150 \mathrm{MHz}\right): \delta=22.2\left(\mathrm{CH}_{2}\right), 28.7\left(\mathrm{CH}_{2}\right), 37.8\left(\mathrm{CH}_{3}\right), 38.3\left(\mathrm{CH}_{3}\right), 50.1\left(\mathrm{CH}_{2}\right), 58.8$ $\left(\mathrm{CH}_{2}\right), 121.8(\mathrm{CH}), 124.6(\mathrm{CH}), 128.6(\mathrm{CH} \mathrm{Ar}), 129.8(\mathrm{CH} \mathrm{Ar}), 129.9(\mathrm{CH}$ Ar $), 135.6(\mathrm{C} \mathrm{Ar}), 148.0$ (C), 171.7 (CAu $t z \mathrm{NHC}), 184.7$ (CAu $n \mathrm{NHC}$ ).

Method B. A mixture of sodium acetate $(0.015 \mathrm{~g}, 0.183 \mathrm{mmol})$, the diimidazolium salt $\mathbf{1}-\mathbf{P F}$ 。 $(0.048 \mathrm{~g}, 0.082 \mathrm{mmol})$ and $\mathrm{AuCl}\left(\mathrm{SMe}_{2}\right)(0.024 \mathrm{~g}, 0.082 \mathrm{mmol})$ in dimethylformamide $(10 \mathrm{~mL})$ was heated and maintained at $120{ }^{\circ} \mathrm{C}$ for $3 \mathrm{~h}$. The mixture was then filtered on Celite and $\mathrm{n}$-hexane $(70$ $\mathrm{mL})$, dichloromethane $(10 \mathrm{~mL})$ and diethyl ether $(50 \mathrm{~mL})$ were added to the filtrate, affording a white solid. The precipitate was filtered and dried under vacuum (yield 77\%). The 'H-NMR spectra show two set of signals, attributable to the complexes $\mathbf{5}$ and $\mathbf{5}$ ', in a ca. 4:1 ratio. Crystals of complex 5 were obtained by slow diffusion of diethyl ether into an acetonitrile solution of the crude mixture. 
Synthesis of 6/6'. A solution of $\mathrm{AuCl}\left(\mathrm{SMe}_{2}\right)(0.033 \mathrm{~g}, 0.113 \mathrm{mmol})$ in acetonitrile $(5 \mathrm{~mL})$ was added to a solution of silver(I) complex $4(0.060 \mathrm{~g}, 0.056 \mathrm{mmol})$ in the same solvent $(5 \mathrm{~mL})$. The reaction mixture was left under stirring for 3 hours at room temperature; afterwards, it was filtered on Celite and the solvent was removed under vacuum in order to obtain a white solid (yield 75\%). Anal. Calcd for $\mathrm{C}_{32} \mathrm{H}_{38} \mathrm{~N}_{10} \mathrm{Au}_{2} \mathrm{P}_{2} \mathrm{~F}_{12}$ : C, 30.83; H, 3.07; N, 11.24\%. Found: C, 30.40; H, 3.15; N, 10.86\%. ESI-MS (positive-ions, $\mathrm{CH}_{3} \mathrm{CN}$ ): $\mathrm{m} / z, 1101.23\left[100 \%, \mathrm{Au}_{2} \mathrm{~L}_{2} \mathrm{PF}_{6}\right]^{+}, \mathrm{L}=n \mathrm{NHC}-t z \mathrm{NHC}$ dicarbene ligand. The 'H NMR spectra show two set of signals, attributable to the complexes $\mathbf{6}$ and 6', in a 1:1 ratio. 6. ' $\mathrm{H} \mathrm{NMR}\left(\mathrm{CD}_{3} \mathrm{CN}, 400 \mathrm{MHz}\right) \delta=2.35\left(\mathrm{~m}, 2 \mathrm{H}, \mathrm{CH}_{2}\right), 2.83\left(\mathrm{~m}, 2 \mathrm{H}, \mathrm{CH}_{2}\right), 3.46(\mathrm{~s}$, $\left.3 \mathrm{H}, \mathrm{CH}_{3}\right), 4.16\left(\mathrm{~m}, 2 \mathrm{H}, \mathrm{CH}_{2}\right), 4.18\left(\mathrm{~s}, 3 \mathrm{H}, \mathrm{CH}_{3}\right), 7.00\left(\mathrm{~d},{ }^{3} \mathrm{~J}_{\mathrm{Hн}}=2.0 \mathrm{~Hz}, 1 \mathrm{H}, \mathrm{CH}\right), 7.18\left(\mathrm{~d},{ }^{3} \mathrm{~J}_{\text {нн }}=2.0 \mathrm{~Hz}\right.$, 1H, CH), $7.45(\mathrm{~m}, 2 \mathrm{H}, \mathrm{CH} \mathrm{Ar}), 7.57(\mathrm{~m}, 1 \mathrm{H}, \mathrm{CH} \mathrm{Ar}), 7.70(\mathrm{~m}, 2 \mathrm{H}, \mathrm{CH} \mathrm{Ar}) .{ }^{13} \mathrm{C}\left\{{ }^{\prime} \mathrm{H}\right\} \mathrm{NMR}\left(\mathrm{CD}_{3} \mathrm{CN}\right.$, $100 \mathrm{MHz}): \delta=21.6\left(\mathrm{CH}_{2}\right), 27.5\left(\mathrm{CH}_{2}\right), 38.0\left(\mathrm{CH}_{3}\right), 38.2\left(\mathrm{CH}_{3}\right), 49.2\left(\mathrm{CH}_{2}\right), 121.0(\mathrm{CH}) 124.2(\mathrm{CH}$ Ar), $124.5(\mathrm{CH}), 130.5$ (CH Ar), 131.5 (CH Ar), 139.9 (C Ar), 148.1 (C), 169.7 (CAu tzNHC), 183.8 (CAu $n$ NHC). Crystals of complex 6 were obtained by slow diffusion of diethyl ether into a solution of the complexes 6 and 6' in acetonitrile. 6'. 'H NMR $\left(\mathrm{CD}_{3} \mathrm{CN}, 400 \mathrm{MHz}\right) \delta=2.65(\mathrm{~m}, 2 \mathrm{H}$, $\left.\mathrm{CH}_{2}\right), 2.99\left(\mathrm{~m}, 2 \mathrm{H}, \mathrm{CH}_{2}\right), 3.34\left(\mathrm{~s}, 3 \mathrm{H}, \mathrm{CH}_{3}\right), 4.16\left(\mathrm{~m}, 2 \mathrm{H}, \mathrm{CH}_{2}\right), 4.19\left(\mathrm{~s}, 3 \mathrm{H}, \mathrm{CH}_{3}\right), 7.13\left(\mathrm{~d}, \mathrm{~J}_{\mathrm{HH}}=2.0\right.$ $\mathrm{Hz}, 1 \mathrm{H}, \mathrm{CH}), 7.27\left(\mathrm{~d},{ }^{3} \mathrm{~J}_{\text {нн }}=2.0 \mathrm{~Hz}, 1 \mathrm{H}, \mathrm{CH}\right), 7.47(\mathrm{~m}, 2 \mathrm{H}, \mathrm{CH}$ Ar), $7.54(\mathrm{~m}, 1 \mathrm{H}, \mathrm{CH} \mathrm{Ar}), 7.70(\mathrm{~m}$, 2H, CH Ar). ${ }^{13} \mathrm{C}\left\{{ }^{\prime} \mathrm{H}\right\}$ NMR $\left(\mathrm{CD}_{3} \mathrm{CN}, 100 \mathrm{MHz}\right): \delta=22.4\left(\mathrm{CH}_{2}\right), 27.9\left(\mathrm{CH}_{2}\right), 38.0\left(\mathrm{CH}_{3}\right), 38.2\left(\mathrm{CH}_{3}\right)$, $49.9\left(\mathrm{CH}_{2}\right), 121.2(\mathrm{CH}), 124.3(\mathrm{CH} \mathrm{Ar}), 124.7(\mathrm{CH}), 130.6(\mathrm{CH} \mathrm{Ar}), 131.4(\mathrm{CH} \mathrm{Ar}), 139.9(\mathrm{C} \mathrm{Ar})$, 147.3 (C), 169.3 (CAu $t z \mathrm{NHC}), 184.5$ (CAu $n \mathrm{NHC})$.

Synthesis of the palladium(II) complexes 8/8'. A solution of $\left[\mathrm{PdCl}_{2}(\mathrm{COD})\right](0.014 \mathrm{~g}, 0.049$ $\mathrm{mmol})$ in acetonitrile $(5 \mathrm{~mL})$ was added to a solution of silver(I) complex $4(0.052 \mathrm{~g}, 0.049 \mathrm{mmol})$ in the same solvent $(5 \mathrm{~mL})$. The reaction mixture was left under stirring for 3 hours at room temperature; afterwards, it was filtered on Celite and the solvent was removed under vacuum, giving a white solid (yield 74\%). HR-MS (positive-ions, $\mathrm{CD}_{3} \mathrm{CN}$ ): $\mathrm{m} / \mathrm{z}$ calcd for $\mathrm{C}_{32} \mathrm{H}_{38} \mathrm{~N}_{10} \mathrm{PdPF}_{6}$ $\left(100 \%,\left[\mathrm{PdL}_{2} \mathrm{PF}_{6}\right]^{+}\right)$813.1957, found 813.2056, L = $n$ NHC- $t z \mathrm{NHC}$ dicarbene ligand. The $\mathrm{H}-\mathrm{NMR}$ spectrum shows two set of signals, attributable to the complexes $\mathbf{8}$ and $\mathbf{8}$ ', in a 3:2 ratio. 8. 'H NMR 
$\left(\mathrm{CD}_{3} \mathrm{CN}, 400 \mathrm{MHz}\right) \delta=2.35\left(\mathrm{~m}, 2 \mathrm{H}, \mathrm{CH}_{2}\right), 2.89\left(\mathrm{~m}, 2 \mathrm{H}, \mathrm{CH}_{2}\right), 3.71\left(\mathrm{~s}, 3 \mathrm{H}, \mathrm{CH}_{3}\right), 3.92\left(\mathrm{~s}, 3 \mathrm{H}, \mathrm{CH}_{3}\right)$, $4.23\left(\mathrm{~m}, 2 \mathrm{H}, \mathrm{CH}_{2}\right), 7.01\left(\mathrm{~d},{ }^{3} \mathrm{~J}_{\mathrm{Hн}}=1.35 \mathrm{~Hz}, 1 \mathrm{H}, \mathrm{CH}\right), 7.04\left(\mathrm{~d},{ }^{3} \mathrm{~J}_{\text {нн }}=1.35 \mathrm{~Hz}, 1 \mathrm{H}, \mathrm{CH}\right), 7.17(\mathrm{~m}, 2 \mathrm{H}$, $\mathrm{CH} \mathrm{Ar}), 7.70(\mathrm{~m}, 3 \mathrm{H}, \mathrm{CH} \mathrm{Ar}) .{ }^{13} \mathrm{C}\left\{{ }^{\prime} \mathrm{H}\right\} \mathrm{NMR}\left(\mathrm{CD}_{3} \mathrm{CN}, 400 \mathrm{MHz}\right): \delta=25.8\left(\mathrm{CH}_{2}\right), 27.4\left(\mathrm{CH}_{2}\right), 37.2$ $\left(\mathrm{CH}_{3}\right), 39.3\left(\mathrm{CH}_{3}\right), 52.0\left(\mathrm{CH}_{2}\right), 124.0(\mathrm{CH}), 124.2(\mathrm{CH}), 126.9(\mathrm{CH} \mathrm{Ar}), 131.0(\mathrm{CH}$ Ar $), 132.0(\mathrm{CH}$ Ar), 140.73 (C Ar), 145.4 (C), 157.0 (CPd $t z N H C), 170.6$ (CPd $n$ NHC),. 8'.'H NMR $\left(\mathrm{CD}_{3} \mathrm{CN}, 400\right.$ $\mathrm{MHz}) \delta=2.89\left(\mathrm{~m}, 2 \mathrm{H}, \mathrm{CH}_{2}\right), 3.40\left(\mathrm{~m}, 2 \mathrm{H}, \mathrm{CH}_{2}\right), 3.71\left(\mathrm{~s}, 3 \mathrm{H}, \mathrm{CH}_{3}\right), 3.92\left(\mathrm{~s}, 3 \mathrm{H}, \mathrm{CH}_{3}\right), 4.13(\mathrm{~m}, 2 \mathrm{H}$, $\left.\mathrm{CH}_{2}\right), 6.90\left(\mathrm{~d},{ }^{3} \mathrm{~J}_{\text {нн }}=1.35 \mathrm{~Hz}, 1 \mathrm{H}, \mathrm{CH}\right), 7.01\left(\mathrm{~d},{ }^{3} \mathrm{~J}_{\text {нн }}=1.35 \mathrm{~Hz}, 1 \mathrm{H}, \mathrm{CH}\right), 7.18(\mathrm{~m}, 2 \mathrm{H}, \mathrm{CH} \mathrm{Ar}), 7.70$ (m, 3H, CH Ar). ${ }^{13} \mathrm{C}\left\{{ }^{1} \mathrm{H}\right\}$ NMR $\left(\mathrm{CD}_{3} \mathrm{CN}, 400 \mathrm{MHz}\right): \delta=23.8\left(\mathrm{CH}_{2}\right), 26.1\left(\mathrm{CH}_{2}\right), 37.1\left(\mathrm{CH}_{3}\right), 39.3$ $\left(\mathrm{CH}_{3}\right), 53.1\left(\mathrm{CH}_{2}\right), 123.8(\mathrm{CH}), 125.3(\mathrm{CH}), 127.1(\mathrm{CH} \mathrm{Ar}), 130.7(\mathrm{CH} \mathrm{Ar}), 132.1(\mathrm{CH}$ Ar $), 140.3(\mathrm{C}$ Ar), $146.1(\mathrm{C}), 170.1$ (CPd $n \mathrm{NHC}),(\mathrm{CPd} t z \mathrm{NHC}$ not detected). Crystals of complex 8 were obtained by slow diffusion of diethyl ether into a solution of the complexes $\mathbf{8}$ and $\mathbf{8}$ ' in acetonitrile. The assignment of the signals to $\mathbf{8}$ or $\mathbf{8}$ ' has been made on the abundance in the 'H NMR spectra, attributing the more intense signals to complex $\mathbf{8}$, the one that crystallizes.

Crystal structure determination of compounds 5, 6, 7 and 8. The crystallographic data for compounds 5, 6, 7 and 8 were collected on a Bruker Apex II single-crystal diffractometer working with monochromatic Mo-K $\alpha$ radiation and equipped with an area detector ${ }^{49}$ The structures were solved by direct methods and refined against $F^{2}$ with SHELXL-2014/7 with anisotropic thermal parameters for all non-hydrogen atoms, ${ }^{50}$ excepted the carbon and oxygen atoms of the diethyl ether solvent molecule in compound 7 that have been refined isotropically. In some cases, the propyl chains of the ligands have been found disordered in two positions and refined with appropriate occupancy factor. Idealized geometries were assigned to the hydrogen atoms. For the molecular graphics, the Program ORTEP-3 for Windows has been used. ${ }^{.1}$ Crystal data for the four compounds are reported in Table 3. Crystallographic data have been deposited with the Cambridge Crystallographic Data Centre as supplementary publication. Copies of the data can be obtained free of charge on application to the CCDC, 12 Union Road, Cambridge CB2 1EZ, U.K. (fax, (+44) 1223 336033; e-mail, deposit@ccdc.cam.ac.uk). 
Table 3. Crystal data for compounds 5, 6, 7 and $\mathbf{8}$.

\begin{tabular}{|c|c|c|c|c|}
\hline Compound & 5 & 6 & 7 & 8 \\
\hline Formula & $\mathrm{C}_{34} \mathrm{H}_{42} \mathrm{Au}_{2} \mathrm{~F}_{12} \mathrm{~N}_{10} \mathrm{P}_{2}$ & $\mathrm{C}_{34} \mathrm{H}_{41} \mathrm{Au}_{2} \mathrm{~F}_{12} \mathrm{~N}_{11} \mathrm{P}_{2}$ & $\mathrm{C}_{40} \mathrm{H}_{50} \mathrm{AgAu}_{2} \mathrm{~F}_{18} \mathrm{~N}_{12} \mathrm{O}_{05} \mathrm{P}_{3}$ & $\mathrm{C}_{36} \mathrm{H}_{44} \mathrm{~F}_{12} \mathrm{~N}_{12} \mathrm{P}_{2} \mathrm{Pd}$ \\
\hline Molecular Weight & 1274.66 & 1287.65 & 1643.63 & 1041.17 \\
\hline Crystal system & Monoclinic & Monoclinic & Monoclinic & Monoclinic \\
\hline Space group & $C 2 / c$ & $C 2 / c$ & $C 2 / c$ & $P 2 / c$ \\
\hline$a[\AA]$ & $8.3231(4)$ & $24.845(2)$ & $22.366(2)$ & $11.917(3)$ \\
\hline$b[\AA]$ & $18.3439(9)$ & $14.7302(12)$ & $23.882(2)$ & $12.117(3)$ \\
\hline$c[\AA]$ & $26.7035(13)$ & $24.302(2)$ & $21.841(2)$ & $15.264(4)$ \\
\hline$\beta\left[^{\circ}\right]$ & $91.709(2)$ & $105.8310(10)$ & $106.733(2)$ & $97.907(5)$ \\
\hline $\mathrm{V}\left[\AA^{3}\right]$ & $4075.2(3)$ & $8556.8(12)$ & $11172.3(18)$ & $2183.0(10)$ \\
\hline Temperature (K) & 200 & 173 & 293 & 173 \\
\hline $\bar{Z}$ & 4 & 8 & 8 & 2 \\
\hline $\mathrm{D}_{\text {call }}\left[\mathrm{gcm}^{-3}\right]$ & 2.078 & 1.999 & 1.954 & 1.584 \\
\hline$\mu\left[\mathrm{cm}^{-1}\right]$ & 7.367 & 7.019 & 5.776 & 0.593 \\
\hline $\mathrm{F}(000)$ & 2448 & 4944 & 6320 & 1056 \\
\hline Reflections collected & 35864 & 55629 & 66312 & 23253 \\
\hline $\begin{array}{l}\text { Independent } \\
\text { reflections }\end{array}$ & 6192 & 10024 & 11118 & 3843 \\
\hline $\begin{array}{l}\text { Reflections in } \\
\text { refinement }\end{array}$ & 5667 & 8133 & 6478 & 2915 \\
\hline$R$ (int) & 0.0539 & 0.0571 & 0.0752 & 0.0618 \\
\hline Refined parameters & 274 & 564 & 686 & 289 \\
\hline $\mathrm{R}_{1}[I>2 \sigma(I)]$ & $\begin{array}{l}\mathrm{R}_{1}=0.0578 \\
\mathrm{wR}_{2}=0.1760\end{array}$ & $\begin{array}{l}\mathrm{R}_{1}=0.0542 \\
\mathrm{wR}_{2}=0.1079\end{array}$ & $\begin{array}{l}\mathrm{R}_{1}=0.0530 \\
\mathrm{wR}_{2}=0.1399\end{array}$ & $\begin{array}{l}\mathrm{R}_{1}=0.0596 \\
\mathrm{wR}_{2}=0.1610\end{array}$ \\
\hline $\mathrm{wR}_{2}$ [all data] & $\begin{array}{l}\mathrm{R}_{1}=0.0605 \\
\mathrm{wR}_{2}=0.1796\end{array}$ & $\begin{array}{l}\mathrm{R}_{1}=0.0706 \\
\mathrm{wR}_{2}=0.1133\end{array}$ & $\begin{array}{l}\mathrm{R}_{1}=0.1003 \\
\mathrm{wR}_{2}=0.1671\end{array}$ & $\begin{array}{l}\mathrm{R}_{1}=0.0785 \\
\mathrm{wR}_{2}=0.1814\end{array}$ \\
\hline
\end{tabular}




\begin{tabular}{|l|l|l|l|l|}
\hline GOF & 1.061 & 1.184 & 1.025 & 1.049 \\
\hline CCDC & 1873190 & 1873191 & 1873192 & 1873193 \\
\hline
\end{tabular}

$\mathrm{R}_{1}=\Sigma \mid \mathrm{Fo}-\mathrm{Fcl} / \Sigma(\mathrm{Fo}) ; \mathrm{wR}_{2}=\left[\Sigma\left[\mathrm{w}\left(\mathrm{FO}^{2}-\mathrm{Fc}^{2}\right)^{2}\right] / \Sigma\left[\mathrm{w}\left(\mathrm{Fo}^{2}\right)^{2}\right]\right]^{12}$.

Luminescence studies. Luminescence spectra were recorded at room temperature, on films obtained by drop casting a sample solution in acetonitrile on a quartz substrate, using an optical fiber bundle coupled to the spectrofluorimeter (Fluorolog-3, Horiba JobinYvon) equipped with double-grating monochromator in both the excitation and emission sides. A $450 \mathrm{~W}$ Xe arc lamp and an R928P Hamamatsu photomultiplier were employed as excitation source and detector, respectively. The emission spectra were corrected for detection and optical spectral response of the spectrofluorimeter supplied by the manufacturer. The excitation spectra were corrected for the spectral distribution of the lamp intensity using a photodiode reference detector. Absolute photoluminescence quantum yields (PLQY) were measured by means of a Spectralon-coated integrating sphere accessory (4”, F-3018, Horiba Jobin-Yvon) fitted in the fluorimeter sample chamber. Three independent measurements were carried out on each sample and the error on PLQY is $20 \%$.

Photoluminescence decay curves were obtained through single-photon experiments using a 295 $\mathrm{nm}$ pulsed LED as excitation sources (Horiba NanoLED). The collected data were analyzed with the Horiba DAS6 Decay Analysis Software.

Computational details. Density Functional Theory (DFT) calculations were carried out with the Amsterdam Density Functional (ADF) program. ${ }^{.254}$ The BLYP ${ }^{55.58}$ density functional was used and the Grimme dispersion was added (BLYP-D3(BJ))..$^{59}$ The zeroth-order regular approximation (ZORA) was chosen include the scalar relativistic effects, as recommended in presence of heavy nuclei. ${ }^{61-63}$ The TZ2P basis set, which is a large uncontracted set of Slater-type orbitals (STOs), of triple- $\zeta$ quality and augmented with two sets of polarization functions on each atom $(2 p$ and $3 d$ in the case of $\mathrm{H}, 3 \mathrm{~d}$ and $4 \mathrm{f}$ in the case of $\mathrm{C}$ and $\mathrm{N}, 6 \mathrm{~g}$ and $7 \mathrm{~h}$ in the case of $\mathrm{Au}$ ), was employed. The frozen- 
core approximation was used for the core electrons: up to 1 s for $\mathrm{C}$ and $\mathrm{N}$, and up to $4 \mathrm{~d}$ in the case of $\mathrm{Au}$, respectively. For the numerical integration the Becke grid was used. ${ }^{6455}$ This level of theory gave reliable results in recent studies on gold complexes.$^{66-68}$ TD-DFT calculations were performed on the optimized geometries of $\mathbf{5 ( f s )}$ and $\mathbf{6}(\mathbf{t})$ in gas-phase, using all-electron TZ2P basis sets for all of the atoms. SAOP, which is an appropriate exchange-correlation potential with the statistical averaging of (model) orbitals, was chosen to calculate the excitation energies ${ }^{6970}$ because it reliably describes the excited states of organometallic compounds. ${ }^{7-13}$ The lowest thirty singlet-singlet as well as singlet-triplet excitations were computed. The lowest triplet states of $\mathbf{5}(\mathbf{f} s)$ and $\mathbf{6}(\mathbf{t})$ were fully optimized in order to estimate the phosphorescence wavelength of $\mathbf{5}(\mathbf{f} s)$ and $\mathbf{6}(\mathbf{t})$; BLYP-D3(DJ) functional combined with TZ2P small core basis set for all the atoms was used in these unrestricted calculations; scalar relativistic effects were included with the ZORA formalism.

\section{ACKNOWLEDGMENTS}

University of Padova is gratefully acknowledged for financial support (CPDA20140431 and Assegno di Ricerca Senior GRIC15V47A). Computational facilities at CINECA were available thanks to the ISCRA grant STREGA (PI: L.O.). This work has been supported in part by La ligue contre le cancer - Grand Est (France). S.B.L. and M.M. gratefully acknowledge the 'Programme de bourses d'excellence Eiffel - Volet Doctorat' for support.

\section{ASSOCIATED CONTENT}

Supporting Information: coordinates of all the computed structures and electronic structure details, NMR spectra of the synthesized compounds.

\section{Notes}

The authors declare no competing financial interest. 


\section{REFERENCES}

(1) Arduengo, A. J.; Harlow, R. L.; Kline, M. A Stable Crystalline Carbene. J. Am. Chem. Soc. 1991, 113, 361-363.

(2) Flanigan, D. M.; Romanov-Michailidis, F.; White, N. A.; Rovis, T. Organocatalytic Reactions Enabled by N-Heterocyclic Carbenes. Chem. Rev. 2015, 115, 9307-9387.

(3) Enders, D.; Niemeier, O.; Henseler, A. Organocatalysis by N-Heterocyclic Carbenes. Chem. Rev. 2007, 107, 5606-5655.

(4) Diez-Gonzalez, S. N-Heterocyclic Carbenes: From Laboratory Curiosities to Efficient Synthetic Tools, 2nd Edition 2017, Cambridge: RSC Catalysis Series, RSC.

(5) Huynh, H. V. The Organometallic chemistry of N-heterocyclic carbenes 2017, Hoboken, NJ: John Wiley \& Sons, Inc.

(6) Hopkinson, M. N.; Richter, C.; Schedler, M.; Glorius, F. An Overview of N-Heterocyclic Carbenes. Nature 2014, 510, 485-496.

(7) Nolan, S. P. N-Heterocyclic Carbenes, Effective Tools for Organometallic Synthesis 2014, Weinheim: Wiley-VCH.

(8) Peris, E. Smart N-Heterocyclic Carbene Ligands in Catalysis. Chem. Rev. 2018, 118, 998810031.

(9) Bellemin-Laponnaz, S.; Dagorne, S. Group 1 and 2 and Early Transition Metal Complexes Bearing N-Heterocyclic Carbene Ligands: Coordination Chemistry, Reactivity, and Applications. Chem. Rev. 2014, 114, 8747-8774. 
(10) Visbal, R.; Gimeno, M. C. N-Heterocyclic Carbene Metal Complexes: Photoluminescence and Applications. Chem. Soc. Rev. 2014, 43, 3551-3574.

(11) Mercs, L.; Albrecht, M. Beyond Catalysis: N-Heterocyclic Carbene Complexes as Components for Medicinal, Luminescent, and Functional Materials Applications. Chem. Soc. Rev. 2010, 39, 1903-1912.

(12) Oehninger, L.; Rubbiani, R.; Ott, I. N-Heterocyclic Carbene Metal Complexes in Medicinal Chemistry. Dalton Trans. 2013, 42, 3269-3284.

(13) Liu, W.; Gust, R. Update on Metal N-Heterocyclic Carbene Complexes as Potential AntiTumor Metallodrugs. Coord. Chem. Rev. 2016, 329, 191-213.

(14) Biffis, A.; Baron, M.; Tubaro, C. Chapter Five - Poly-NHC Complexes of Transition Metals: Recent Applications and New Trends. In Advances in Organometallic Chemistry; Pérez, P. J., Ed.; Academic Press, 2015; Vol. 63, pp 203-288.

(15) Gardiner, M. G.; Ho, C. C. Recent Advances in Bidentate Bis(N-Heterocyclic Carbene) Transition Metal Complexes and Their Applications in Metal-Mediated Reactions. Coord. Chem. Rev. 2018, 375, 373-388.

(16) Poyatos, M.; Mata, J. A.; Peris, E. Complexes with Poly(N-Heterocyclic Carbene) Ligands: Structural Features and Catalytic Applications. Chem. Rev. 2009, 109, 3677-3707.

(17) Leung, C. H.; Incarvito, C. D.; Crabtree, R. H. Interplay of Linker, N- Substituent, and Counterion Effects in the Formation and Geometrical Distortion of $N$ - Heterocyclic Biscarbene Complexes of Rhodium(I). Organometallics 2006, 25, 6099-6107.

(18) Mercs, L.; Neels, A.; Stoeckli-Evans, H.; Albrecht, M. Probing Intermetallic Coupling in Dinuclear N-Heterocyclic Carbene Ruthenium(II) Complexes. Inorg. Chem. 2011, 50, 8188-8196. 
(19) Nelson, D. J.; Nolan, S. P. Quantifying and Understanding the Electronic Properties of NHeterocyclic Carbenes. Chem. Soc. Rev. 2013, 42, 6723-6753.

(20) Schuster, O.; Yang, L.; Raubenheimer, H. G.; Albrecht, M. Beyond Conventional $N$ Heterocyclic Carbenes: Abnormal, Remote, and Other Classes of NHC Ligands with Reduced Heteroatom Stabilization. Chem. Rev. 2009, 109, 3445-3478.

(21) Donnelly, K. F.; Petronilho, A.; Albrecht, M. Application of 1,2,3-Triazolylidenes as Versatile NHC-Type Ligands: Synthesis, Properties, and Application in Catalysis and Beyond. Chem. Commun. 2013, 49, 1145-1159.

(22) Mata, J. A.; Hahn, F. E.; Peris, E. Heterometallic Complexes, Tandem Catalysis and Catalytic Cooperativity. Chem. Sci. 2014, 5, 1723-1732.

(23) Pell, T. P.; Wilson, D. J. D.; Skelton, B. W.; Dutton, J. L.; Barnard, P. J. Heterobimetallic N -Heterocyclic Carbene Complexes: A Synthetic, Spectroscopic, and Theoretical Study. Inorg. Chem. 2016, 55, 6882-6891.

(24) Sluijter, S. N.; Elsevier, C. J. Synthesis and Reactivity of Heteroditopic Dicarbene Rhodium(I) and Iridium(I) Complexes Bearing Chelating 1,2,3-Triazolylidene-Imidazolylidene Ligands. Organometallics 2014, 33, 6389-6397.

(25) Mendoza-Espinosa, D.; Alvarez-Hernández, A.; Angeles-Beltrán, D.; Negrón-Silva, G. E.; Suárez-Castillo, O. R.; Vásquez-Pérez, J. M. Bridged $N$-Heterocyclic/Mesoionic (NHC/MIC) Heterodicarbenes as Ligands for Transition Metal Complexes. Inorg. Chem. 2017, 56, 2092-2099.

(26) Huynh, H. V.; Jothibasu, R. Syntheses and Catalytic Activities of Pd(II) Dicarbene and Hetero-Dicarbene Complexes. J. Organomet. Chem. 2011, 696, 3369-3375.

(27) Yuan, D.; Huynh, H. V. Hetero-Dicarbene Complexes of Palladium(II): Syntheses and Catalytic Activities. Organometallics 2014, 33, 6033-6043. 
(28) Baron, M.; Tubaro, C.; Biffis, A.; Basato, M.; Graiff, C.; Poater, A.; Cavallo, L.; Armaroli, N.; Accorsi, G. Blue-Emitting Dinuclear N-Heterocyclic Dicarbene Gold(I) Complex Featuring a Nearly Unit Quantum Yield. Inorg. Chem. 2012, 51, 1778-1784.

(29) Baron, M.; Tubaro, C.; Basato, M.; Isse, A. A.; Gennaro, A.; Cavallo, L.; Graiff, C.; Dolmella, A.; Falivene, L.; Caporaso, L. Insights into the Halogen Oxidative Addition Reaction to Dinuclear Gold(I) Di(NHC) Complexes. Chem. - Eur. J. 2016, 22, 10211-10224.

(30) Benhamou, L.; Chardon, E.; Lavigne, G.; Bellemin-Laponnaz, S.; César, V. Synthetic Routes to N-Heterocyclic Carbene Precursors. Chem. Rev. 2011, 111 (4), 2705-2733.

(31) Khan, S. S.; Liebscher, J. Synthesis of New Dicationic Azolium Salts and Their Application as NHC Precursors in Suzuki-Miyaura Coupling. Synthesis 2010, 2010, 2609-2615.

(32) Mejuto, C.; Guisado-Barrios, G.; Gusev, D.; Peris, E. First Homoleptic MIC and Heteroleptic NHC-MIC Coordination Cages from 1,3,5-Triphenylbenzene-Bridged Tris-MIC and Tris-NHC Ligands. Chem. Commun. 2015, 51, 13914-13917.

(33) Sluijter, S. N. Multidentate Di-N-Heterocyclic Carbene Ligands for Transition Metal Catalyzed Hydrogenation Reactions. 2015. PhD thesis, University of Amsterdam.

(34) Rieb, J.; Dominelli, B.; Mayer, D.; Jandl, C.; Drechsel, J.; Heydenreuter, W.; Sieber, S. A.; Kühn, F. E. Influence of Wing-Tip Substituents and Reaction Conditions on the Structure, Properties and Cytotoxicity of $\mathrm{Ag}$ ( I )- and $\mathrm{Au}(\mathrm{I})$-Bis(NHC) Complexes. Dalton Trans. 2017, 46, $2722-2735$.

(35) Zhong, R.; Pöthig, A.; Mayer, D. C.; Jandl, C.; Altmann, P. J.; Herrmann, W. A.; Kühn, F. E. Spectroscopic and Structural Properties of Bridge-Functionalized Dinuclear Coinage-Metal $(\mathrm{Cu}$, Ag, and Au) NHC Complexes: A Comparative Study. Organometallics 2015, 34, 2573-2579. 
(36) Barnard, P. J.; Baker, M. V.; Berners-Price, S. J.; Skelton, B. W.; White, A. H. Dinuclear Gold(I) Complexes of Bridging Bidentate Carbene Ligands: Synthesis, Structure and Spectroscopic Characterisation. Dalton Trans. 2004, 1038-1047.

(37) Gil-Rubio, J.; Cámara, V.; Bautista, D.; Vicente, J. Mono- and Dinuclear Ag(I), Au(I), and $\mathrm{Au}(\mathrm{III})$ Metallamacrocycles Containing $N$-Heterocyclic Dicarbene Ligands. Inorg. Chem. 2013, 52, 4071-4083.

(38) Altmann, P. J.; Pöthig, A. Pillarplexes: A Metal-Organic Class of Supramolecular Hosts. J. Am. Chem. Soc. 2016, 138, 13171-13174.

(39) Kobialka, S.; Müller-Tautges, C.; Schmidt, M. T. S.; Schnakenburg, G.; Hollóczki, O.; Kirchner, B.; Engeser, M. Stretch Out or Fold Back? Conformations of Dinuclear Gold(I) $N$ Heterocyclic Carbene Macrocycles. Inorg. Chem. 2015, 54, 6100-6111.

(40) (a) Tubaro, C.; Baron, M.; Costante, M.; Basato, M.; Biffis, A.; Gennaro, A.; Ahmed Isse, A.; Graiff, C.; Accorsi, G. Dinuclear Gold(I) Complexes with Propylene Bridged N -Heterocyclic Dicarbene Ligands: Synthesis, Structures, and Trends in Reactivities and Properties. Dalton Trans. 2013, 42, 10952-10963. (b) Chen, C.; Qiu, H.-Y.; Liu, A.-L.; Chen, D.; Tang, G.-P.; Chen, W.-Z. Mixed Gold-Silver Clusters Possessing N-Heterocyclic Carbenes: Synthesis, Structural Characterization, and Cytotoxicity. Wuji Huaxue Xuebao 2011, 27, 1423. (c) Skelton, B. W.; Baker, M. V.; Wedlock, L. E.; Berners-Price, S. J. CCDC 1839964: Experimental Crystal Structure Determination, 2018, DOI:10.5517/ccdc.csd.cc1zrmp1.

(41) Barnard, P. J.; Baker, M. V.; Berners-Price, S. J.; Skelton, B. W.; White, A. H. Dinuclear Gold(I) Complexes of Bridging Bidentate Carbene Ligands: Synthesis, Structure and Spectroscopic Characterisation. Dalton Trans. 2004, 1038-1047. 
(42) Che, C.-M.; Lai, S.-W. Structural and Spectroscopic Evidence for Weak Metal-Metal Interactions and Metal-Substrate Exciplex Formations in D10 Metal Complexes. Coord. Chem. Rev. 2005, 249, 1296-1309.

(43) Buscemi, G.; Basato, M.; Biffis, A.; Gennaro, A.; Isse, A. A.; Natile, M. M.; Tubaro, C. Electronic Properties of Chelating Dicarbene Palladium Complexes: A Combined Electrochemical, NMR and XPS Investigation. J. Organomet. Chem. 2010, 695, 2359-2365.

(44) Pinter, P.; Biffis, A.; Tubaro, C.; Tenne, M.; Kaliner, M.; Strassner, T. Palladium(II) Complexes with Electron-Poor, 4,5-Disubstituted Diimidazol-2-Ylidene Ligands: Synthesis, Characterization and Catalytic Activity. Dalton Trans. 2015, 44, 9391-9399.

(45) Munz, D.; Poethig, A.; Tronnier, A.; Strassner, T. Ortho-Phenylene Bridged Palladium BisN-Heterocyclic Carbene Complexes: Synthesis, Structure and Catalysis. Dalton Trans. 2013, 42, $7297-7304$.

(46) Zamora, M. T.; Ferguson, M. J.; McDonald, R.; Cowie, M. Unsymmetrical Dicarbenes Based on $N$-Heterocyclic/Mesoionic Carbene Frameworks: A Stepwise Metalation Strategy for the Generation of a Dicarbene-Bridged Mixed-Metal Pd/Rh Complex. Organometallics 2012, 31, $5463-5477$.

(47) Saravanakumar, R.; Ramkumar, V.; Sankararaman, S. Synthesis and Structure of 1,4Diphenyl-3-Methyl-1,2,3-Triazol-5-Ylidene Palladium Complexes and Application in Catalytic Hydroarylation of Alkynes. Organometallics 2011, 30, 1689-1694.

(48) Wright, J. R.; Young, P. C.; Lucas, N. T.; Lee, A.-L.; Crowley, J. D. Gold(I) and Palladium(II) Complexes of 1,3,4-Trisubstituted 1,2,3-Triazol-5-Ylidene “Click" Carbenes: Systematic Study of the Electronic and Steric Influence on Catalytic Activity. Organometallics 2013, 32, 7065-7076. 
(49) APEX II v2012.2-0 Software User Guide, SAINT, version 7.06a, SADABS, version 2.01, Bruker AXS Inc., Madison, WI, 2008.

(50) Sheldrick, G. M. A Short History of SHELX. Acta Crystallogr. A 2008, 64, 112-122.

(51) Farrugia, L. J. ORTEP-3 for Windows-a version of ORTEP-III with a Graphical User Interface (GUI). J. Appl. Cryst. 1997, 30, 565.

(52) Baerends, E. J.; Ellis, D. E.; Ros, P. Self-Consistent Molecular Hartree-Fock-Slater Calculations I. The Computational Procedure. Chem. Phys. 1973, 2, 41-51.

(53) Velde, G. te; Bickelhaupt, F. M.; Baerends, E. J.; Guerra, C. F.; Gisbergen, S. J. A. van; Snijders, J. G.; Ziegler, T. Chemistry with ADF. J. Comput. Chem. 2001, 22, 931-967.

(54) Computer code ADF2016 E. J. Baerends, et al. (SCM, Theoretical Chemistry, Vrije Universiteit, Amsterdam, The Netherlands, 2016).

(55) Becke, A. D. Density-Functional Exchange-Energy Approximation with Correct Asymptotic Behavior. Phys. Rev. A 1988, 38, 3098-3100.

(56) Lee, C.; Yang, W.; Parr, R. G. Development of the Colle-Salvetti Correlation-Energy Formula into a Functional of the Electron Density. Phys. Rev. B 1988, 37, 785-789.

(57) Johnson, B. G.; Gill, P. M. W.; Pople, J. A. The Performance of a Family of Density Functional Methods. J. Chem. Phys. 1993, 98, 5612-5626.

(58) Russo, T. V.; Martin, R. L.; Hay, P. J. Density Functional Calculations on First-row Transition Metals. J. Chem. Phys. 1994, 101, 7729-7737.

(59) Grimme, S.; Ehrlich, S.; Goerigk, L. Effect of the Damping Function in Dispersion Corrected Density Functional Theory. J. Comput. Chem. 2011, 32, 1456-1465. 
(60) van Lenthe, E.; Baerends, E. J.; Snijders, J. G. Relativistic Total Energy Using Regular Approximations. J. Chem. Phys. 1994, 101, 9783-9792.

(61) Zaccaria, F.; Wolters, L. P.; Guerra, C. F.; Orian, L. Insights on Selenium and Tellurium Diaryldichalcogenides: A Benchmark DFT Study. J. Comput. Chem. 2016, 37, 1672-1680.

(62) Santi, S.; Durante, C.; Donoli, A.; Bisello, A.; Orian, L.; Ganis, P.; Ceccon, A.; Benetollo, F. Intervalence Charge Transfer in Cationic Heterotrinuclear $\mathrm{Fe}(\mathrm{III})-\mathrm{Rh}(\mathrm{I})-\mathrm{Cr}(0)$ Triads of the Polyaromatic Cyclopentadienyl-Indenyl Ligand. Organometallics 2010, 29, 2046-2053.

(63) Orian, L.; Zeist, W.-J. van; Bickelhaupt, F. M. Linkage Isomerism of Nitriles in Rhodium Half-Sandwich Metallacycles. Organometallics 2008, 27, 4028-4030.

(64) Becke, A. D. A Multicenter Numerical Integration Scheme for Polyatomic Molecules. J. Chem. Phys. 1988, 88, 2547-2553.

(65) Franchini, M.; Philipsen, P. H. T.; Visscher, L. The Becke Fuzzy Cells Integration Scheme in the Amsterdam Density Functional Program Suite. J. Comput. Chem. 2013, 34, 1819-1827.

(66) Baron, M.; Tubaro, C.; Cairoli, M. L. C.; Orian, L.; Bogialli, S.; Basato, M.; Natile, M. M.; Graiff, C. Gold(III) Bis(Di- $N$-Heterocyclic Carbene) Square Planar Trication with Axial Ligand Interactions with Bromides from $\mathrm{Ag} / \mathrm{Br}$ Counteranion Assemblies. Organometallics 2017, 36, $2285-2292$.

(67) Baron, M.; Dall'Anese, A.; Tubaro, C.; Orian, L.; Di Marco, V.; Bogialli, S.; Graiff, C.; Basato, M. A Square Planar Gold(III) Bis-(1,1'-Dimethyl-3,3'-Methylene-Diimidazol-2,2'Diylidene) Trication as an Efficient and Selective Receptor towards Halogen Anions: The Cooperative Effect of $\mathrm{Au} \cdots \mathrm{X}$ and X $\cdots \mathrm{HC}$ Interactions. Dalton Trans. 2018, 47, 935-945.

(68) Brands, M. B.; Nitsch, J.; Guerra, C. F. Relevance of Orbital Interactions and Pauli Repulsion in the Metal-Metal Bond of Coinage Metals. Inorg. Chem. 2018, 57, 2603-2608. 
(69) Gritsenko, O. V.; Schipper, P. R. T.; Baerends, E. J. Approximation of the ExchangeCorrelation Kohn-Sham Potential with a Statistical Average of Different Orbital Model Potentials. Chem. Phys. Lett. 1999, 302, 199-207.

(70) Schipper, P. R. T.; Gritsenko, O. V.; van Gisbergen, S. J. A.; Baerends, E. J. Molecular Calculations of Excitation Energies and (Hyper)Polarizabilities with a Statistical Average of Orbital Model Exchange-Correlation Potentials. J. Chem. Phys. 2000, 112, 1344-1352.

(71) Scuppa, S.; Orian, L.; Donoli, A.; Santi, S.; Meneghetti, M. Anti-Kasha’s Rule Fluorescence Emission in (2-Ferrocenyl)Indene Generated by a Twisted Intramolecular Charge-Transfer (TICT) Process. J. Phys. Chem. A 2011, 115, 8344-8349.

(72) Orian, L.; Scuppa, S.; Santi, S.; Meneghetti, M. Large Excited State Two Photon Absorptions in the near Infrared Region of Surprisingly Stable Radical Cations of (Ferrocenyl)Indenes. Phys. Chem. Chem. Phys. 2013, 15, 12971-12976.

(73) Rossi, S.; Bisello, A.; Cardena, R.; Orian, L.; Santi, S. Benzodithiophene and Benzotrithiophene as $\pi$ Cores for Two- and Three-Blade Propeller-Shaped Ferrocenyl-Based Conjugated Systems. Eur. J. Org. Chem. 2017, 2017, 5966-5974. 


\section{FOR TABLE OF CONTENTS USE ONLY}

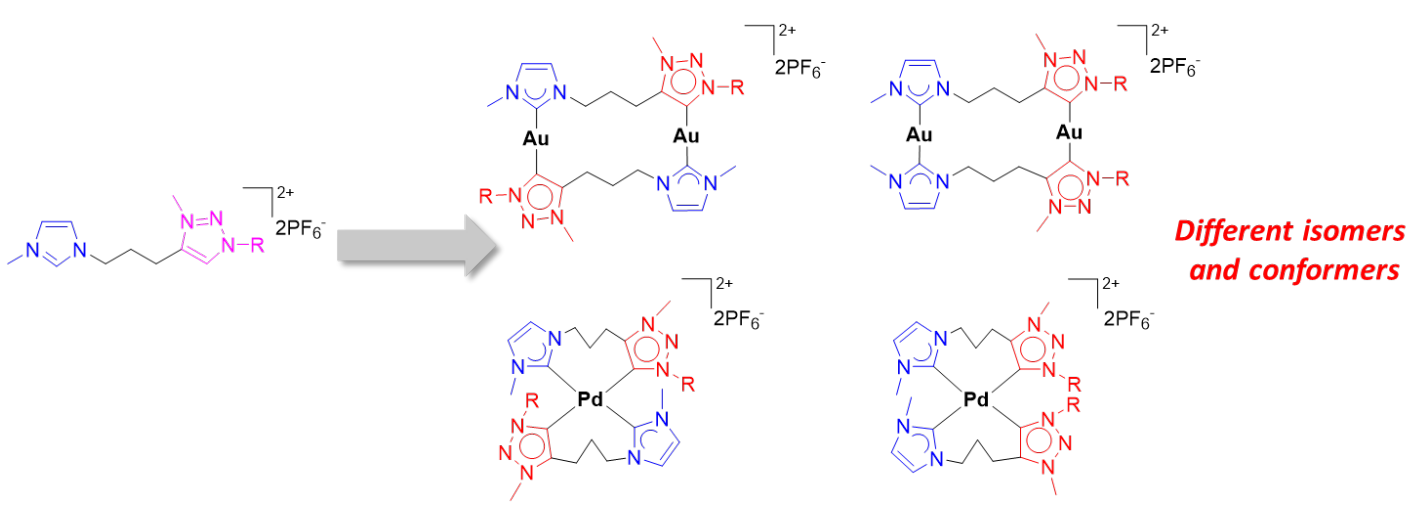

